\title{
APPLICATIONS OF ISOTOPE GEOCHEMISTRY TO THE RECONSTRUCTION OF YUCCA MOUNTAIN, NEVADA, PALEOHYDROLOGY - STATUS OF INVESTIGATIONS: JUNE 1996
}

U.S. GEOLOGICAL SURVEY

Open-File Report 98-83

$$
\text { USGS/OFR - }-98-83
$$

\section{RECEIVED \\ SEP 28 P998 \\ OSTI}

Prepared in cooperation with the NEVADA OPERATIONS OFFICE, U.S. DEPARTMENT OF ENERY, under Interagency Agreement DE-Al08-97NV12033

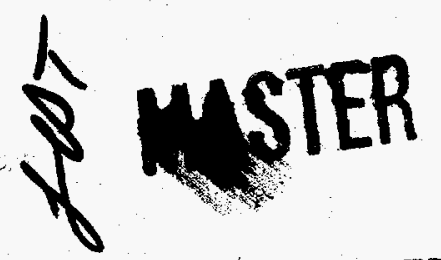




\section{DISCLAIMER}

This report was prepared as an account of work sponsored by an agency of the United States Government. Neither the United States Government nor any agency thereof, nor any of their employees, makes any warranty, express or implied, or assumes any legal liability or responsibility for the accuracy, completeness, or usefulness of any information, apparatus, product, or process disclosed, or represents that its use would not infringe privately owned rights. Reference herein to any specific commercial product, process, or service by trade name, trademark, manufacturer, or otherwise does not necessarily constitute or imply its endorsement, recommendation, or favoring by the United States Government or any agency thereof. The views and opinions of authors expressed herein do not necessarily state or reflect those of the United States Government or any agency thereof. 


\section{DISCLAIMER}

Portions of this document may be illegible in electronic image products. Images are produced from the best available original document. 


\section{Applications of Isotope Geochemistry to the Reconstruction of Yucca Mountain, Nevada, Paleohydrology-Status of Investigations: June 1996}

By Joseph F. Whelan, Richard J. Moscati, Sarah B.M. Allerton, and Brian D. Marshall

U.S. GEOLOGICAL SURVEY

Open-File Report 98-83

Prepared in cooperation with the NEVADA OPERATIONS OFFICE, U.S. DEPARTMENT OF ENERGY, under Interagency Agreement DE-Al08-97NV12033 


\section{U.S. DEPARTMENT OF THE INTERIOR \\ BRUCE BABBITT, Secretary}

\section{U.S. GEOLOGICAL SURVEY}

Thomas J. Casadevall, Acting Director

The use of firm, trade, and brand names in this report is for identification purposes only and does not constitute endorsement by the U.S. Geological Survey.

For additional information write to:

District Chief

U.S. Geological Survey

Box 25046, Mail Stop 415

Denver Federal Center

Denver, CO 80225-0046
Copies of this report can be purchased from:

U.S. Geological Survey

Information Services

Box 25286

Federal Center

Denver, CO 80225 


\section{CONTENTS}

Abstract.
Introduction
Sample Distribution
Sampling and analytical methods
Paragenesis of Exploratory Studies Facility Occurrences
Most recent event: Calcite or opal? - Precipitation or dissolution?
Dissolution events within the unsaturated zone?

FIGURES

1. Maps showing location of the Yucca Mountain region, Nevada, the potential repository site, the Bullfrog Mine, sampled boreholes, Trench 14, and the Exploratory Studies Facility

2. Map showing location of the Exploratory Studies Facility, topographic features, prominent faults,

and the locations of sampled secondary mineralization occurrences near Yucca Mountain, Nevada .

3. Schematic illustrations of the typical paragenetic sequences found (a) in lithophysal cavities and (b) on

fracture surfaces.

4a.-4h. Photomicrographs showing:

4a. Late botryoidal opal with rhombic overgrowths of calcite that are, in turn, locally pimpled with tiny opaline spheres

4b. Late botryoidal opal grown on calcite and partially engulfed by a later stage of calcite

4c. Opal with overgrowths of a later opaline stage followed by calcite overgrowth coated with botryoidal opal that is, in turn, partially buried by late calcite

4d. Bladed calcite crystals with scepter-like terminations.....

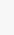
3 3 6 21

4e. Pyramidal to spire-like calcite forms from the basal zone of lithophysal secondary calcite mineralization .....

4f. Basal dissolution zone, with calcite microspeleothems or meniscus cements...

4g. Unetched surface of calcite crystal .

4h. Pitted surface of apparently etched calcite crystal face

5-7. Graphs showing:

5. Distribution of unsaturated-zone delta carbon-13 and delta oxygen-18 values of calcite plotted against depth

6. Distribution of delta carbon-13 and delta oxygen-18 values of Exploratory Studies Facility calcite samples plotted against distance from the portal.

7. Preliminary radiogenic strontium isotopic compositions plotted against the stable carbon and oxygen isotopic compositions, and correlation of delta carbon-13 and delta oxygen-18 values of Exploratory Studies Facility calcite..

8-9. Histograms showing:

8. Yucca Mountainun unsaturated zone secondary silica delta oxygen-18 values...

9. Distribution of carbon-14 ages from Exploratory Studies Facility calcite occurrences 


\section{TABLE}

1. Major stratigraphic units in the Late Cenozoic volcanic rock sequence of the Yucca Mountian area, Nevada......

\begin{tabular}{rll}
\hline Multiply & By & To obtain \\
\hline centimeter $(\mathrm{cm})$ & 0.3937 & inch \\
meter $(\mathrm{m})$ & 3.2808 & foot \\
kilometer $(\mathrm{km})$ & 0.6214 & mile \\
\hline
\end{tabular}

Degree Celsius $\left({ }^{\circ} \mathrm{C}\right)$ may be converted to degree Fahrenheit $\left({ }^{\circ} \mathrm{F}\right)$ by using the following equation:

$$
{ }^{\circ} \mathrm{F}=9 / 5\left({ }^{\circ} \mathrm{C}\right)+32
$$

Sea level: In this report "sea level" refers to the National Geodetic Vertical Datum of 1929 (NGVD of 1929)-a geodetic datum derived from a general adjustment of the first-order level nets of both the United States and Canada, formerly called Sea Level Datum of 1929.

The following terms also are used in this report:

$\mathrm{Ma}$

millions of years old

$\mathrm{Ka}$

thousands of years old

Ky

thousands of years

$\mathrm{Pz}$

Paleozoic

ESF

Exploratory Studies Facility

SMOW

Standard Mean Ocean Water

PDB

Pee Dee Belemnite

${ }^{\circ} \mathrm{C} / \mathrm{km}$

degrees Celsius per kilometer

AMS

Accelerator Mass Spectrometer

pmc

percent modern carbon

$\mathrm{N}$

normal 


\title{
Applications of Isotope Geochemistry to the Reconstruction of Yucca Mountain, Nevada, Paleohydrology-Status of Investigations: June 1996
}

\author{
By Joseph F. Whelan, Richard J. Moscati, Sarah B.M. Allerton, and Brian D. Marshall
}

\section{Abstract}

Tunneling of the Exploratory Studies Facility has offered the opportunity to sample and examine occurrences of secondary mineralization found in the unsaturated-zone tuffs of Yucca Mountain, Nevada. Petrographic and paragenetic analyses, calcite and silica-phase stable isotopic analyses, and preliminary strontium tracer isotope and radiocarbon age analyses of these samples indicate that (1) an early stage of secondary mineralization consisting largely of chalcedony and quartz, but possibly with or slightly preceded by calcite, probably formed at warmer than ambient temperatures; (2) later secondary mineralization consisting of calcite and opal appears completely consistent with formation from percolation of surface infiltration whose solute load and carbon isotopic compositions reflect passage through the overlying soils; (3) based on textural studies, all unsaturated-zone secondary mineral occurrences exposed within the Exploratory Studies Facility tunnel, with the exception of the vapor-phase assemblages that formed at high temperatures during cooling of the tuffs, probably formed in unsaturated settings; and (4) calcite radiocarbon ages, based on preliminary results, have not been compromised by post-depositional exchange with carbon-bearing water and gases in the unsaturated zone.

\section{INTRODUCTION}

Yucca Mountain, Nevada, is presently under evaluation as a potential national subsurface repository for high-level radioactive wastes. Current designs for the potential repository would emplace wastes within the sequence of welded and nonwelded tuffs in the thick unsaturated zone of the mountain, several hundred meters below ground surface but still well above the modem water table. Siting within the unsaturated zone is advantageous in that it isolates the wastes from regional ground water; unfortunately, it also introduces climate-driven infiltration and percolation through the unsaturated zone as site-evaluation variables. Although present climate is arid, past climates have ranged to much wetter (R.M. Forester, U.S. Geological Survey, oral commun., 1997), and future climates are likely to be wetter, as well. The effects of future climatic changes on site performance are critical issues for site suitability assessment.

Efforts to reconstruct the hydrologic response of Yucca Mountain to past climatic variations, especially within the unsaturated zone, have focused on textural and geochemical study of secondary minerals deposited from past percolation fluxes and ground water. This report discusses stable carbon and oxygen isotopic data and mineral parageneses determined from secondary calcite and silica mineralization and describes reconnaissance radiogenic strontium $(\mathrm{Sr})$ isotopic and carbon-14 $\left({ }^{14} \mathrm{C}\right)$ age data and their applicability to paleohydrologic and paleoclimatic studies. Most of the new data reported here were collected from samples of secondary mineral occurrences accessed during construction of the Exploratory Studies Facility (ESF) tunnel. Construction of the tunnel was a fundamental component of site-characterization studies of Yucca Mountain. 
Evolution of understanding of the origins of secondary minerals within the Yucca Mountain tuffs is reflected in several papers (Whelan and Stuckless, 1990 and 1992; Whelan and others, 1994; and J.F. Whelan and R.J. Moscati, U.S. Geological Survey, written commun., 1997). The latter report summarized the evolution of studies of the secondary calcite and silica minerals within Yucca Mountain and updated understanding of the processes responsible for deposition of these minerals. It stated that:

"investigation of the secondary minerals within the mountain, spurred by the study of the surficial deposits, revealed that the calcite and opal commonly coating fractures and lining open cavities in the unsaturated zone were deposited during downward percolation of meteoric waters ... These fluids reflected the oxygen isotopic signature of precipitation ... and had acquired distinctive carbon and strontium isotopic signatures from the thin overlying soils during infiltration that were recorded by the secondary calcite and opal deposited by the fluids as they percolated through the tuffs." (Emphasis added.)

A stage of the secondary calcite, paragenetically early but volumetrically minor, is characterized by uncommonly carbon- $13\left({ }^{13} \mathrm{C}\right)$-enriched isotopic compositions and by delta oxygen- $18\left(\delta^{18} \mathrm{O}\right)$ values that decrease more rapidly with depth than succeeding calcite stages. That steeper $\delta^{18} \mathrm{O}$ decrease may record a steeper geothermal gradient during formation of the paragenetically early calcite. Data collected from ESF occurrences during 1996 indicate that, at least locally, this paragenetically early calcite is volumetrically more abundant than drill hole studies had indicated.

Other studies of secondary mineralization in the ESF estimated Pleistocene percolation fluxes through the unsaturated zone by measuring secondary calcite and opal volumes and inferring rates of secondary calcite and opal formation from thorium-230/uranium $\left({ }^{230} \mathrm{Th} / \mathrm{U}\right)$ and ${ }^{14} \mathrm{C}$ age determinations. If that early calcite stage were formed much earlier and under significantly different hydrologic conditions, as is suggested by its atypical $\delta^{13} \mathrm{C}$ systematics, then its inclusion in the mineral record used to estimate past percolation fluxes might result in erroneous flux estimates.

This report describes efforts to map the parageneses of secondary mineral occurrences (appendix 1) within the ESF, discusses the stable carbon and oxygen isotopic compositions of calcite, the stable oxygen isotopic compositions of multiple stages of silica (chalcedony, quartz, and opal) deposition and some provisional ${ }^{87} \mathrm{Sr} /{ }^{86} \mathrm{Sr}$ ratios of calcite, and evaluates the apparent timing of latest calcite formation in several occurrences from the ESF based on provisional ${ }^{14} \mathrm{C}$ age determinations. The purpose of this investigation is to use this isotopic characterization of secondary minerals to trace isotopic variations in the water that percolated through the sequence of volcanic rocks at Yucca Mountain and to reconstruct the hydrologic response of Yucca Mountain to past climatic variations. This study focuses mainly on samples obtained in excavations of the ESF and expands interpretations based on earlier studies. Sampling and examination of secondary mineralization within the ESF has increased our understanding of the distribution of secondary minerals and demonstrated a greater extent and thickness of secondary mineral occurrences, the very delicate nature of some of the calcite crystal forms, and a more widespread distribution of opal than had been observed from studies of drill-core occurrences.

Yucca Mountain is located near the western boundary of the Nevada Test Site in southwestern Nevada about $140 \mathrm{~km}$ northwest of Las Vegas and lies in the north-central part of the Basin and Range physiographic province. It consists of a series of rugged north-trending fault-block ridges composed of volcanic rocks with a general eastward tilt of $5^{\circ}$ to $10^{\circ}$ (Scott and Bonk, 1984). A thick section of Tertiary volcanic rocks (table 1) overlies Paleozoic sedimentary strata in the Yucca Mountain region (Byers and others, 1976) with units of the 12.8 to 12.7 Ma Paintbrush Group (Sawyer and others, 1994) forming most exposures (Christiansen and Lipman, 1965; Scott and Bonk, 1984). Two voluminous densely welded ashflow tuffs of the Paintbrush Group underlie Yucca Mountain (the Tiva Canyon and Topopah Spring Tuffs), separated by a much thinner interval of mostly nonwelded pyroclastic rocks (Buesch and others, 1996); the tuffaceous rocks are greater than $3,000 \mathrm{~m}$ thick in some places (Snyder and Carr, 1984). Welding and consolidation of the thick tuffaceous units produced zones of abundant lithophysal cavities, where lithification around gas bubbles formed open cavities in the rock. High-angle faults locally exhibit displacements of several hundred meters (Carr, 1984; Scott and Bonk, 1984); numerous studies (summarized in Volume 1, Part A, of the Site Characterization Plan for Yucca Mountain; U.S. Department of Energy, 1988, section 1.3) have shown that the tectonic setting of Yucca Mountain is complex, with the area situated at the intersection of contrasting structural zones. 
This document was originally a milestone report to the Department of Energy Yucca Mountain Project, submitted in June of 1996. This version has benefited from several thorough editorial reviews, but the content herein is consistent with the original 1996 report.

\section{SAMPLE DISTRIBUTION}

Since tunneling began in 1995, 145 occurrences of secondary mineralization within the ESF have been collected for the USGS, 88 by the Bureau of Reclamation during fiscal year (FY) 1995 as part of the

Table 1. Major stratigraphic units in the Late Cenozoic volcanic rock sequence of the Yucca Mountain area. Ages are given in millions of years (Ma). Modified from Sawyer and others 91994) and Buesch and others (1996).

\begin{tabular}{|c|c|}
\hline Unit & Age $(\mathrm{Ma})^{1}$ \\
\hline \multicolumn{2}{|l|}{ Timber Mountain Group } \\
\hline Ammonia Tanks Tuff & 11.45 \\
\hline Rainier Mesa Tuff & 11.6 \\
\hline Post-Tiva Canyon pre-Rainier Mesa rhyolites ${ }^{2}$ & 12.5 \\
\hline \multicolumn{2}{|l|}{ Paintbrush Group } \\
\hline Tiva Canyon Tuff & 12.7 \\
\hline Yucca Mountain Tuff & -- \\
\hline Pah Canyon Tuff & -- \\
\hline Topopah Spring Tuff & 12.8 \\
\hline Calico Hills Formation & 12.9 \\
\hline \multicolumn{2}{|l|}{ Crater Flat Group } \\
\hline Prow Pass Tuff & - \\
\hline Bullfrog Tuff & 13.25 \\
\hline Tram Tuff & -- \\
\hline Lithic Ridge Tuff & 14.0 \\
\hline \multicolumn{2}{|c|}{$\begin{array}{l}{ }^{1} \text { Ages have not been determined for all units. } \\
{ }^{2} \text { This informal grouping represents motiple myolites of small } \\
\text { extent enpted from multiple sources at the margins of calderas } \\
\text { as the Timber Mountain caldera complex north of Yucca Moun- } \\
\text { Correlations are incompletely understood for all such identified } \\
\text { lites and calderas. }\end{array}$} \\
\hline
\end{tabular}

Consolidated Sampling Program and 57 during FY 1996 by the USGS (Yucca Mountain Project) Isotope Hydrology Team. The location of the ESF and the locations of newly sampled boreholes (USW SD-7, USW SD-12, USW VH-1, USW VH-2, USW $\mathrm{UZ}-14$, and UE-25 a \#5) are shown on figure 1; the approximate locations of those ESF occurrences that have been sampled are shown on figure 2 .

\section{Sampling and analytical methods}

Secondary mineral occurrences were examined from drill cores UE-25 a \#7, USW UZ-14, USW SD-7, USW SD-12, and USW VH-2 and from underground exposures in the ESF. These samples are tabulated in appendix 2 along with each sample's Hydrogenic Deposits (HD) sample tracking number. Individual occurrences from drill core are designated by borehole name and depth below surface. Position within the ESF is defined by station number (a station is located every $100 \mathrm{~m}$ beginning at the North Portal) and incremental distance from the previous station. For instance, an occurrence collected 1456.7 meters from the North Portal would be designated as station $14+56.7$. Occurrences within the ESF are listed in appendix 2 by their distance from the North Portal.

Sample textures, morphology, and mineralogy were described from hand specimens and petrographic thin sections. Hand specimens were examined under a stereomicroscope at magnifications up to $75 \mathrm{x}$ at visible and short-wave ultraviolet (UV) wavelengths. Minerals were identified by their habit, reaction to hydrochloric acid, hardness, and UV fluorescence. Thick (100- to 200-micrometers) polished sections were prepared from most samples for examination in plane-polarized light and observation of cathodoluminescence $(C L)$ behavior. Scanning-electron microscopic (SEM) observations were made on gold-coated sections and specimen fragments on a Cambridge StereoScan $250 \mathrm{MkJI}$ instrument at an accelerating voltage of $20 \mathrm{kV}$ and a working distance of 20 millimeters.

Calcite was sampled from hand specimens for stable isotope analysis by milling with dental burs. Sampling of individual mineralization stages, when such were distinct, was accomplished by milling under low-power magnification. Layers as thin as 0.1 millimeter could be milled from calcite crystal faces and from channels as narrow as 0.5 millimeter within mineral sequences.

Silica minerals were sampled by chipping or gouging from hand specimens or by milling with a diamond-impregnated dental bit. Impurities were removed by hand-picking, and the separates were then digested at room temperature in $0.1 \mathrm{~N} \mathrm{HCl}$ to remove possible carbonate impurities. 


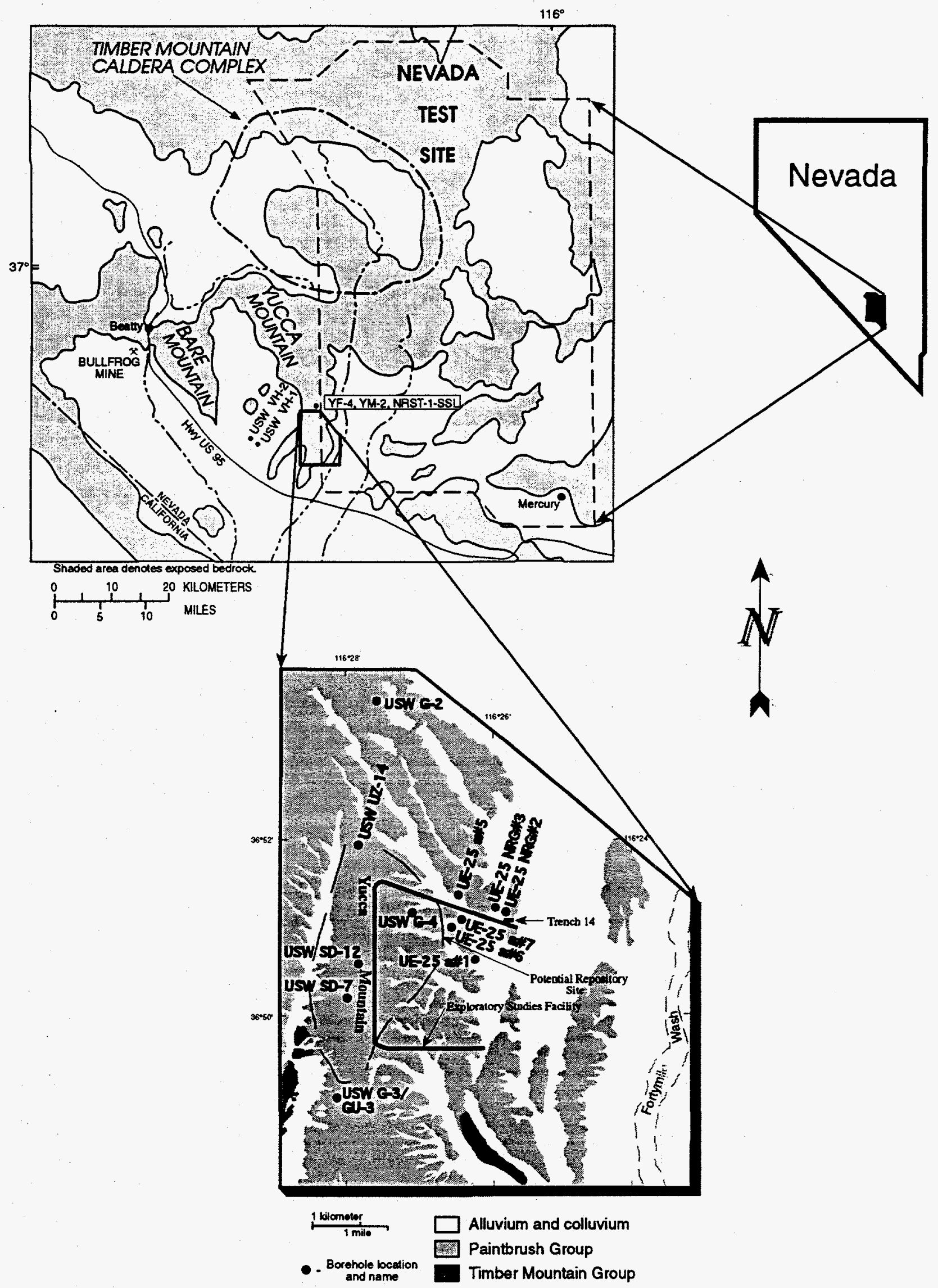

Figure 1. Location of the Yucca Mountain region, Nevada, the potential repository site, the Bullfrog Mine, sampled boreholes, Trench 14, and the Exploratory Studies Facility. 


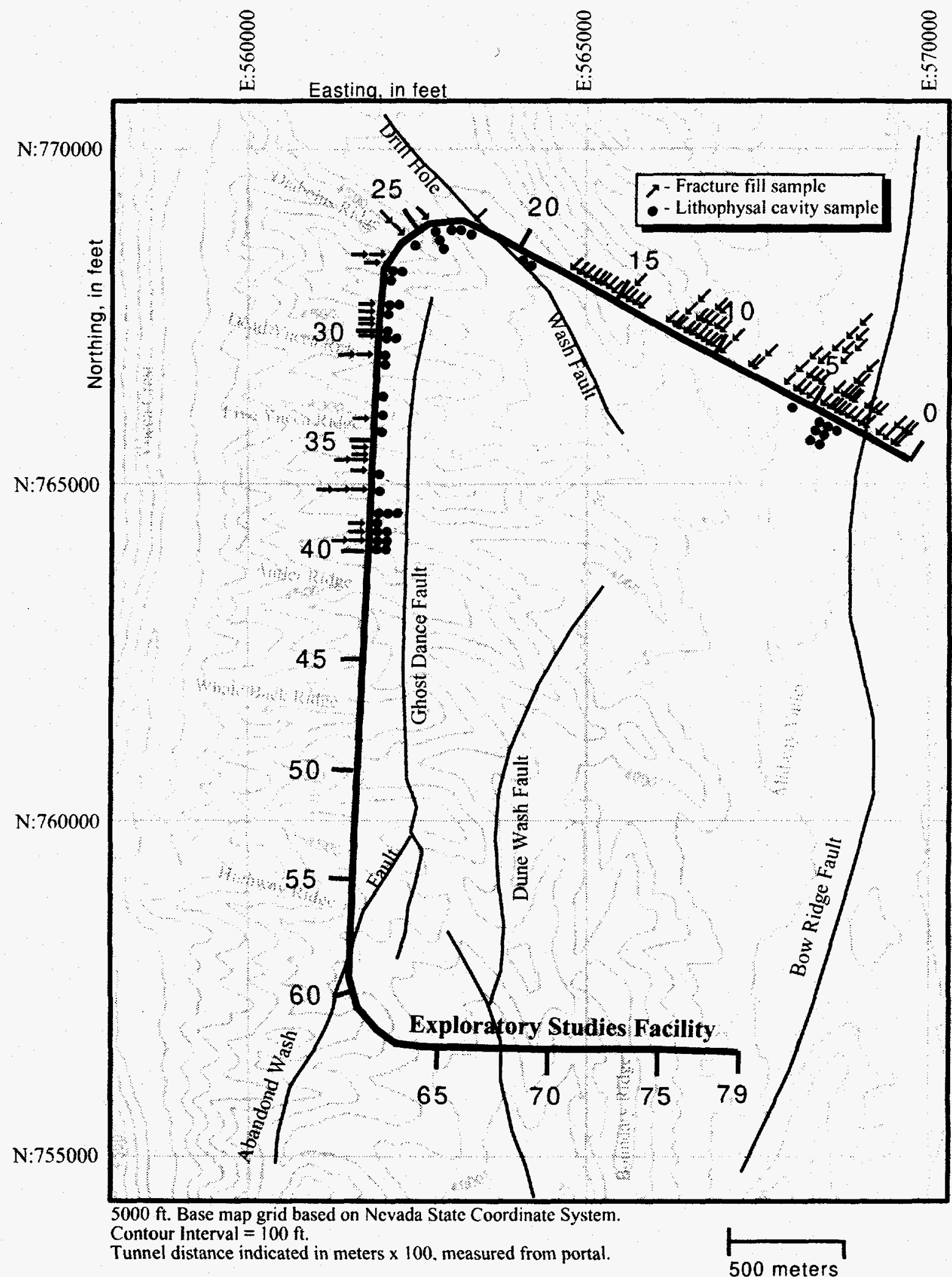

Figure 2. Location of the Exploratory Studies Facility, topographic features, prominent faults, and the locations of sampled secondary mineralization occurrences, near Yucca Mountain, Nevada. 
Procedures based on conventional techniques first described by McCrea (1950) were used to extract $\mathrm{CO}_{2}$ from carbonates. Oxygen was extracted from the silica separates by stepwise fluorination for more highly hydrated opaline separates according to procedures described by Haimson and Knauth (1983), or by reaction with $\mathrm{BrF}_{5}$ for less-hydrated separates according to procedures developed by Clayton and Mayeda (1963), and converted to $\mathrm{CO}_{2}$ by reaction with hot graphite. Stable carbon and oxygen isotopic compositions of the extracted $\mathrm{CO}_{2}$ were determined on Finnigan MAT 251 or 252 mass spectrometers. Stable isotope compositions are reported as the per mil deviations of the samples from the international standards PDB (for carbon) and SMOW (for oxygen). Delta $(\delta)$ deviations are defined as

$$
\left.\delta=\left(\left(R_{\text {sample }}-R_{\text {standard }}\right) / R_{\text {standard }}\right)\right) X 1000
$$

where $\mathrm{R}$ is the ratio of the heavier isotope $\left({ }^{13} \mathrm{C}\right.$ or $\left.{ }^{18} \mathrm{O}\right)$ to the lighter isotope $\left({ }^{12} \mathrm{C}\right.$ or ${ }^{16} \mathrm{O}$, respectively) in the sample or standard $\mathrm{CO}_{2}$. One-sigma reproducibility of the $\delta^{13} \mathrm{C}$ and $\delta^{18} \mathrm{O}$ values is routinely less than or equal to 0.1 and 0.15 per mil, respectively.

Ninety-eight aliquots of laboratory standard NBS-19 (or its in-house equivalent, TS-1) analyzed during the course of data collection had average $\delta^{13} \mathrm{C}$ and $\delta^{18} \mathrm{O}$ values of $1.91 \pm 0.02$ per mil and $28.32 \pm 0.15$ per mil, respectively, compared to accepted values of 1.92 and 28.65 per mil. All $\delta^{18} \mathrm{O}$ values reported in appendix 2 have been adjusted by +0.30 per mil to correct the measured deviation from the accepted value for NBS-19.

Strontium isotopic compositions $\left({ }^{87} \mathrm{Sr} /{ }^{86} \mathrm{Sr}\right)$ vere measured on samples of calcite from the ESF. Da! (about 10-mg) subsamples of calcite were milled or chipped from natural or sawn surfaces. The subsamples were leached with hydrochloric acid to remove calcite from opal and wall rock, and any residues were dried and weighed to determine the actual amcunts of calcite that was dissolved. Strontium was separated using standard ion-exchange methods, and istopic compositions were determined on an automated multi-collector solid-source mass spectrometer. The reported ${ }^{87} \mathrm{Sr} /{ }^{86} \mathrm{Sr}$ ratios are within about \pm 0.005 per cent of the actual value.

\section{PARAGENESIS OF EXPLORATORY STUDIES FACILITY OCCURRENCES}

Paragenesis is defined as the order of mineral formation or a characteristic association or occurrence of minerals (Gary and others, 1974). A paragenesis may include a wide variety of minerals or only one or two; it may be simple, or it may be complex with numerous resolvable depositional events. Within a mineralization sequence, many textural relationships may be clear, some may seem clear but are not, and some will be ambiguous. Paragenetic descriptions always contain an element of subjectivity imparted by formulating a genetic framework from empirical observations - they are, as such, interpretative. Appendix 1 lists preliminary descriptions of paragenetic sequences of about 70 samples collected in the ESF during FY 1996 by the USGS. That appendix also contains a brief glossary of some of the terminology used in the following discussion. The occurrences described in appendix 1 represent only about half of the occurrences collected to date (February 1996) from the ESF.

Within the brittle and fractured welded tufls exposed in the ESF, post-vapor-phase secondary minerals are generally restricted to the footwalls of fractures or the floors of lithophysae. This relation indicates that the fluids that precipitated secondary minerals did not fill these open spaces; that is, those tuffs were not within the saturated zone at the time of secondary mineralization. Mineralizing fluids apparently filled only the smallest-aperture fractures and formed, at most, only shallow pools on the floors of lithophysae.

\section{Lithophysal-cavily parageneses differ from} those in steeply dipping fractures in that the cavities have thicker accumulations of secondary minerals, they contain larger free-growing crystals of calcite that commonly display unusual bladed habits, and they contain much more opal (figs. $3 a$ and b). Lithophysalcavity paragenetic sequences begin with vapor-phase tridymite ( \pm hematite), deposited while the tufs were still hot. Where lithophysae are connected to percolation-flux fracture pathways, those lithophysae may host later calcite and silica minerals.

The earliest secondary mineralization found in such lithophysae consists of massive silica (undifferentiated quartz and chalcedony, possibly with minor opal) with, locally, minor calcite that appears to underlie the massive silica. Calcite, with irregularly

6 Applications of lsotope Geochemistry to the Reconstruction of Yucca Mountain, Nevada, Paleohydrology-Status of Investigations: June 1996 

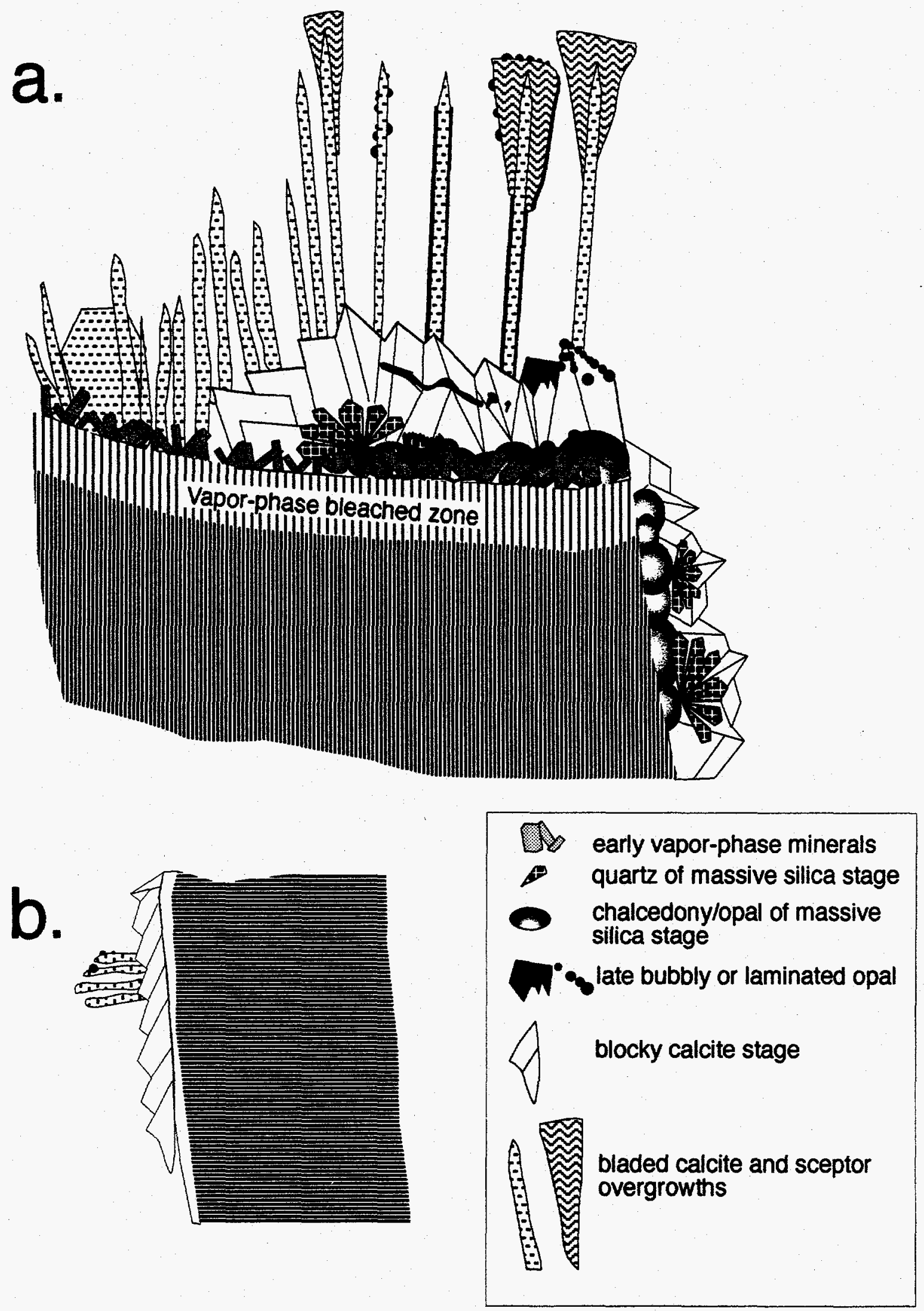

Figure 3. Schematic illustrations of the typical paragenetic sequences found (a) in lithophysal cavities and (b) on fracture surfaces. Descriptive terminology is defined in the glossary included in Appendix 1. 
distributed opal (both in time and space), generally completes the paragenesis. Defined paragenetic stages are, therefore, early massive silica ( \pm calcite) and later main-stage calcite ( \pm opal). Main-stage calcite and opal, as defined here, are pertinent to model estimations of past flux.

Secondary mineral habits vary somewhat within the main stage of lithophysae. Early main-stage calcite within the lithophysae is commonly blocky or tabular. Later main-stage calcite, however, commonly occurs as unusual bladed crystals, typically thin at the base and flaring outward at the top, a habit that results in a scepter-like cross section (figure 4d). Opal may be found throughout the main stage although it is typically more common in the later part. Opal most commonly occurs as scattered spheres or botryoidal to colloform masses (figures $4 a-c$ ) but locally forms thin laminated coatings. Thin-section observations indicate that opal deposition is commonly preceded or accompanied by dissolution of calcite substrates.

Secondary mineral parageneses in steeply dipping fractures differ in habit and mineral abundance from those in lithophysae. Steeply dipping fractures generally contain only blocky to tabular calcite, locally on patches of early-stage massive silica. The sceptered calcite blades and small-bubbled or laminated opal found in lithophysal cavities are rare in steeply-dipping fractures. In the more horizontal fractures, however, the paragenetic sequences are similar to those found flooring lithophysae. This structural control indicates that spatial geometries that retard or halt flow, such as lithophysae or flat-lying fractures, promote formation of the coarse-bladed calcile as well as opal, perhaps because such settings allow solutions to pond and solutes to concentrate through evaporation.

\section{Most Recent Event: Calcite or opal? - Precipitation or dissolution?}

Dating the most recent record of percolation fluxes is important for correlation with regional climatic reconstructions and to provide bounds for assessment of performance of a potential repository. Observing the outer, free-growth surface of mineralization and identifying whether calcite or opal was the last-formed mineral seems straightforward, bearing in mind that the most recent evidence of percolation flux might be mineral dissolution. Scanning-electron microscope observations, however, have revealed complex cycles of latest calcite/opal formation (figures $4 a-c$ ). These observations show that most calcite crystal faces appear fresh (figures $4 b, d$, and $g$ ). Some calcite crystal faces, however, appear pitted (figure 4h) which may indicate calcite dissolution (Vaniman and Chipera, 1996). Dating of materials from these outermost surfaces may, therefore, determine the age of most recent mineral deposition or, if the last event was mineral dissolution, the maximum age of the corrosion event. Either age constraint provides useful information, because correlating climatic states with percolation fluxes (and chemistries) that resulted in secondary mineral dissolution is as important as identifying those climates that produced mineralizing percolation.

\section{Dissolution events within the unsaturated zone?}

Many secondary mineral occurrences within the ESF, particularly those flooring lithophysae, appear to have been corroded around their basal attachment to the tuffaceous substrate (noted in appendix 1 as "basal dissolution"). This basal dissolution is local, commonly affecting only part of an occurrence that otherwise consists of firmly attached and tightly intergrown calcite crystals with pristine youngest crystal faces. Basal dissolution created voids several millimeters high by centimeters wide, a sort of small-scale cavernous porosity. Some of the calcite remnants in these "dissolution" zones are adomed with tiny, toothlike, calcite forms that appear to be overgrowths postdating dissolution (figures $4 \mathrm{e}$ and $\mathrm{f}$ ). In fracture settings, basal dissolution is expressed as loosening of the attaching layer resulting in coatings that lie loosely on the fracture walls.

In many instances, the secondary mineral substrates are more permeable than the secondary mineralization coatings or growths they host, especially the bleached and altered margins associated with vapor-phase mineralization of lithophysae and fractured tuffs. In the laboratory, water dripped onto the bleached margin of a lithophysal cavity moved through the altered matrix and, within seconds, produced obvious wetting of the matrix 10 to 15 centimeters away. The high permeability of the altered rims of lithophysae provides a means for percolating water, perhaps at low flux rates, to contact and dissolve calcite from the base of a lithophysal occurrence without corroding the later calcite in the occurrence. 


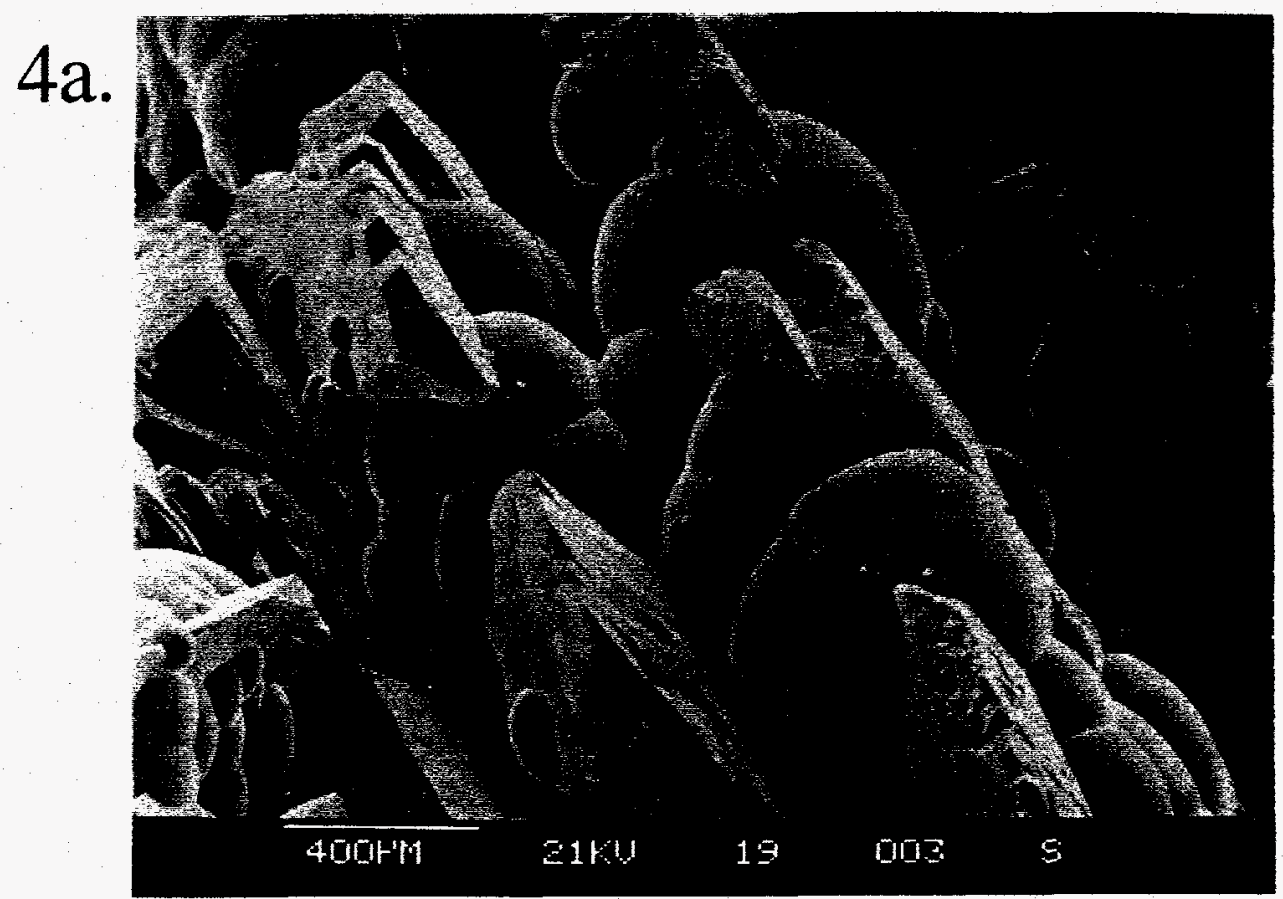

Figure 4a. Photomicrograph of late botryoidal opal with rhombic overgrowths of calcite that are, in turn, locally pimpled with tiny opaline spheres. Scale bar indicates $\mathbf{4 0 0}$ microns.

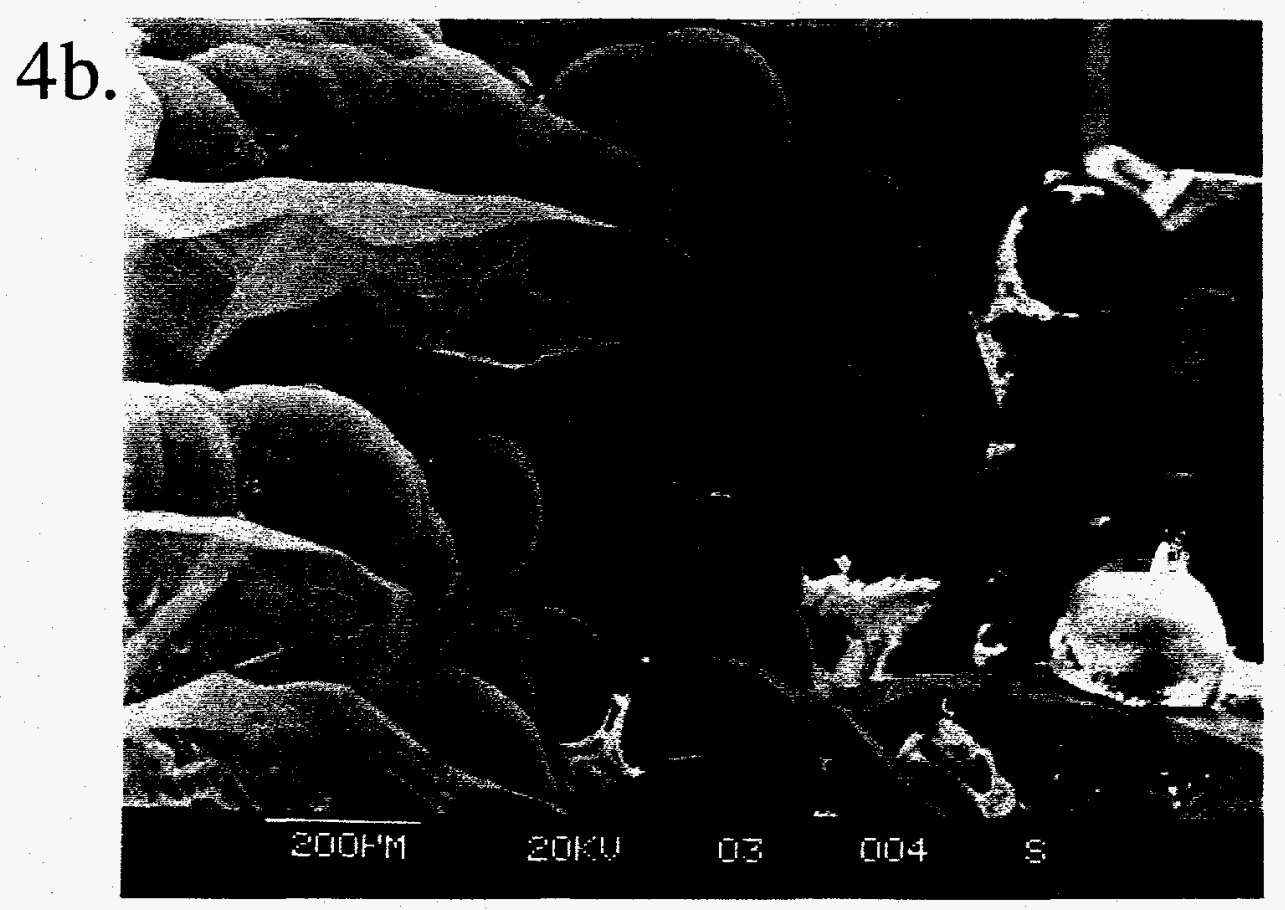

Figure 4b. Photomicrograph of late botryoidal opal on calcite (not shown) partially engulfed by a later stage of calcite. Note the clean uncorroded surfaces of the calcite and opal. Scale bar indicates 200 microns. 


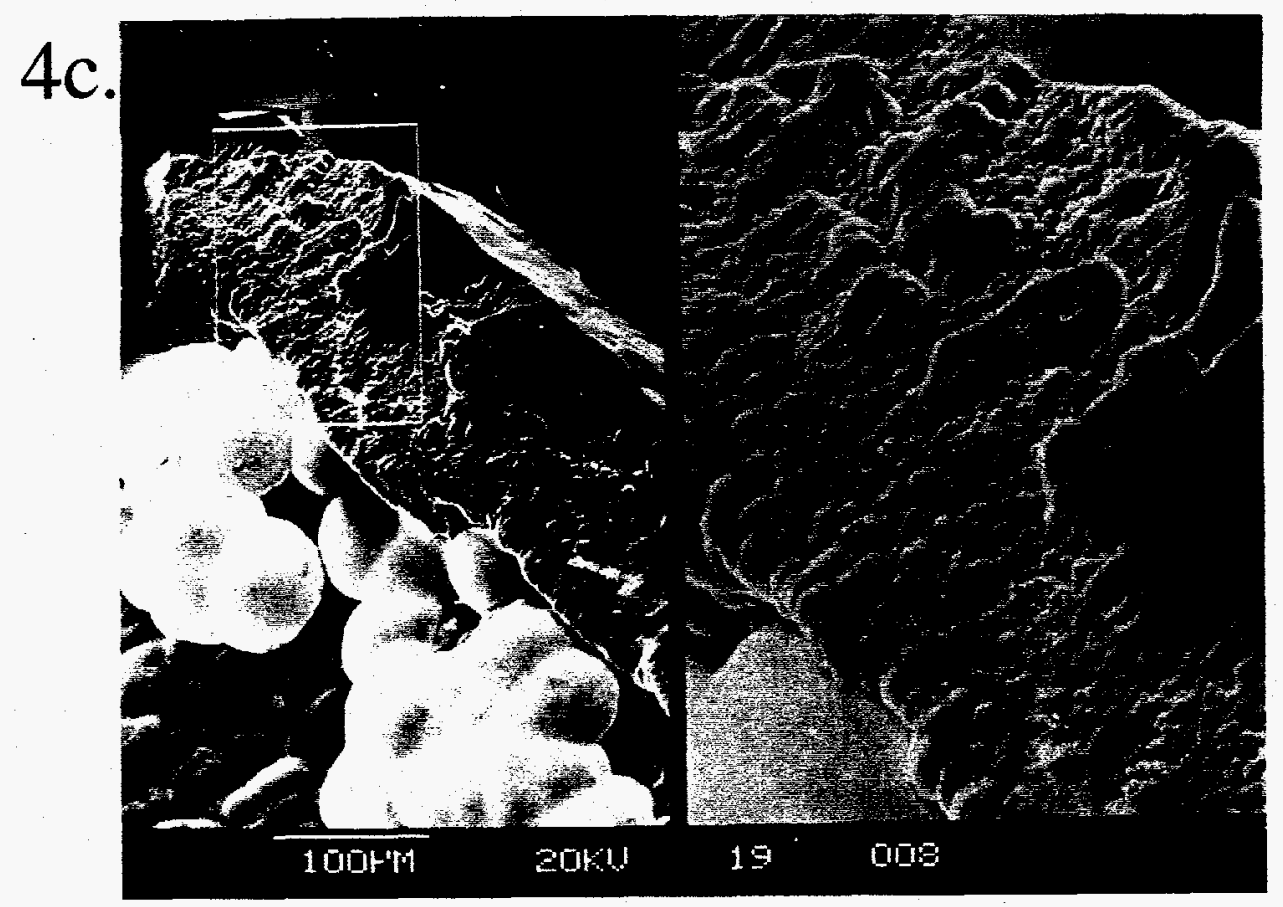

Figure 4c. Photomicrograph of opal (lower left in left image) with overgrowths of a later opaline stage (white spheroids) followed by calcite overgrowth coated with botryoidal opal that is, in turn, partially buried by late calcite. Image on the right is an approximately $3 \times$ enlargement of the later mineralization stages. Scale bar indicates 100 microns.

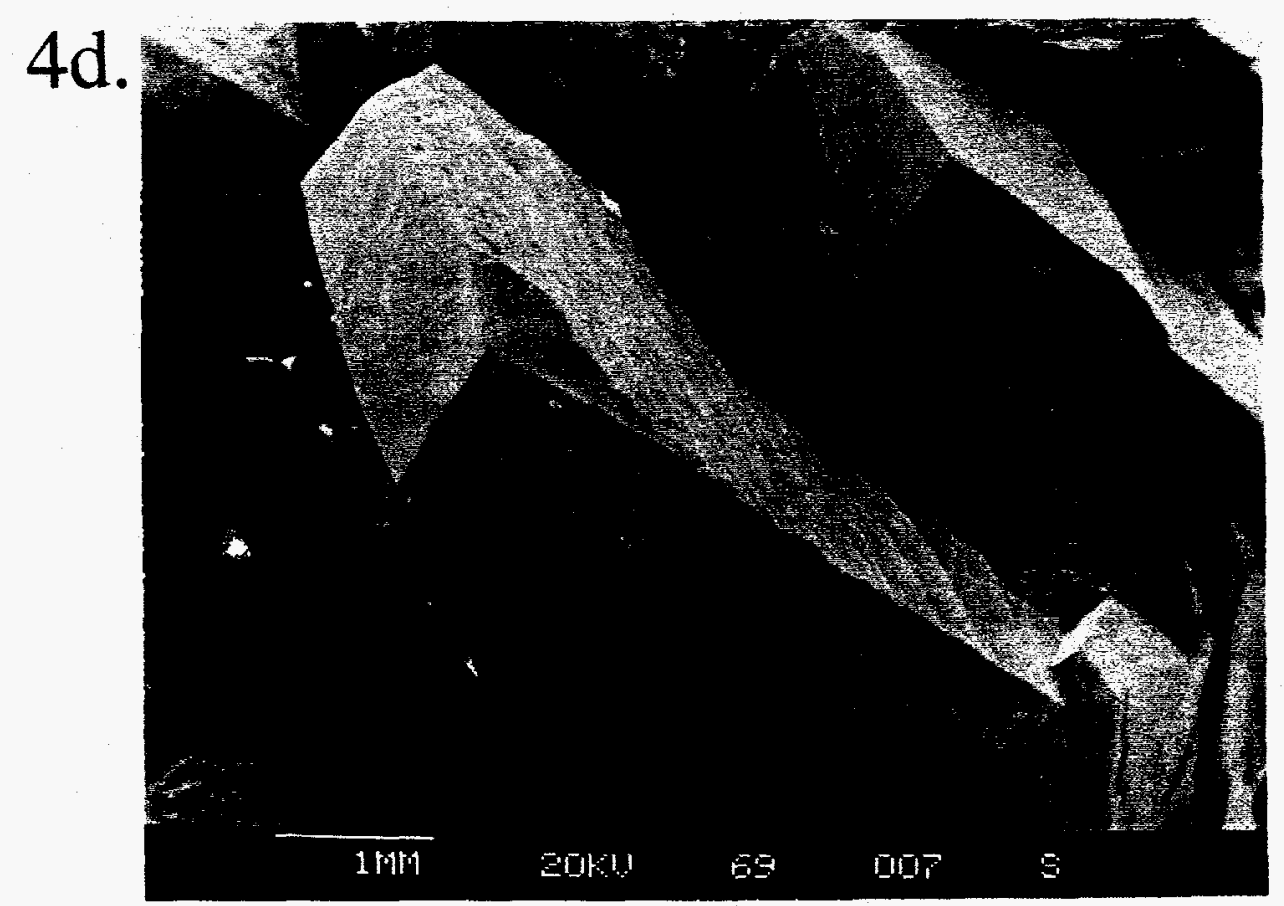

Figure 4d. Photomicrograph of bladed calcite crystals with scepter-like terminations. Scale bar indicates 1 millimeter.

10 Applications of isotope Geochemistry to the Reconstruction of Yucca Mountain, Nevada, Paleohydrology-Status of Investigations: June 1996 


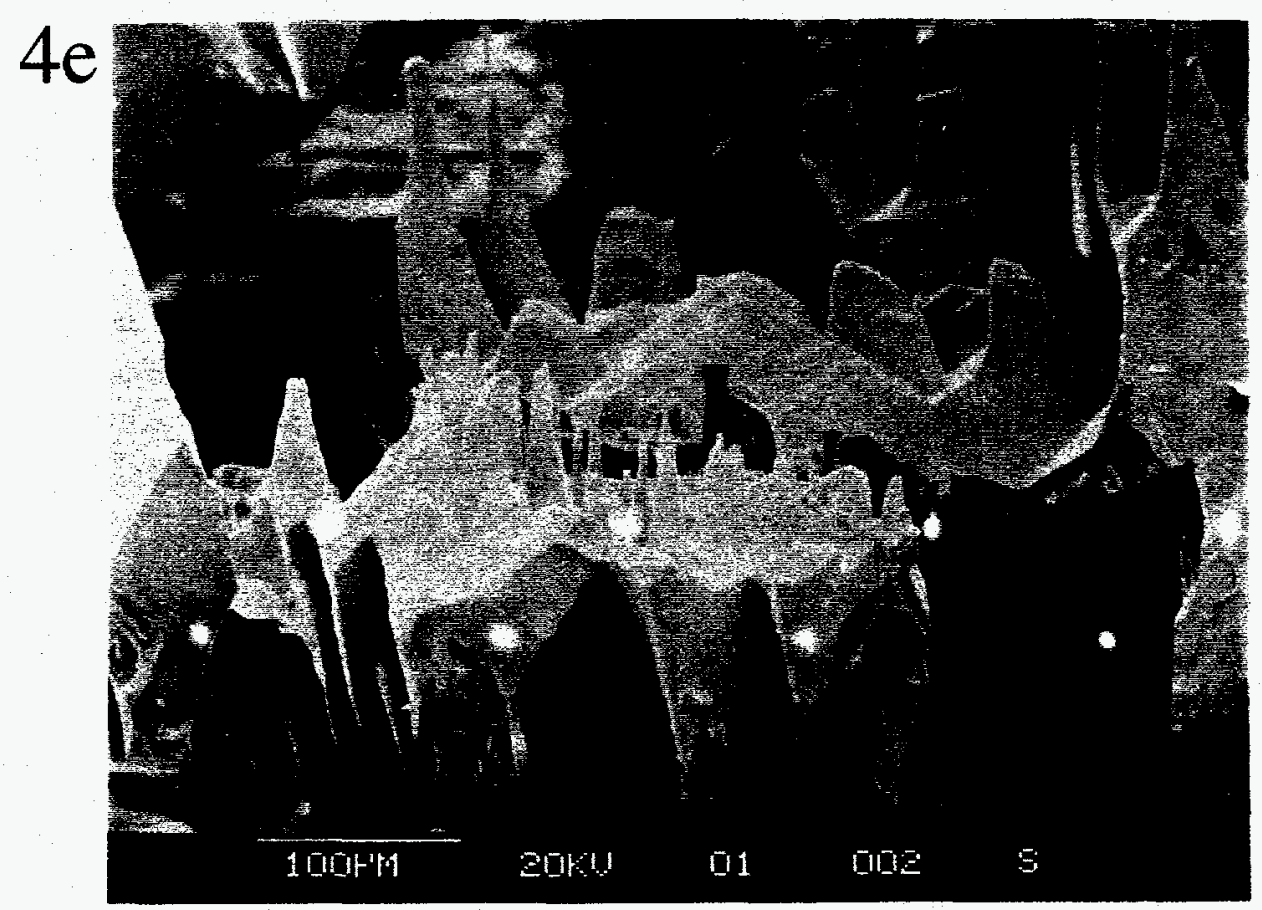

Figure 4e. Photomicrograph of pyramidal to spire-like calcite forms on the basal zone of lithophysal secondary calcite mineralization apparently corroded by later solutions; the relatively fresh faces of this calcite indicate that it may be neoformed and postdate the dissolution event. Scale bar indicates 100 microns.

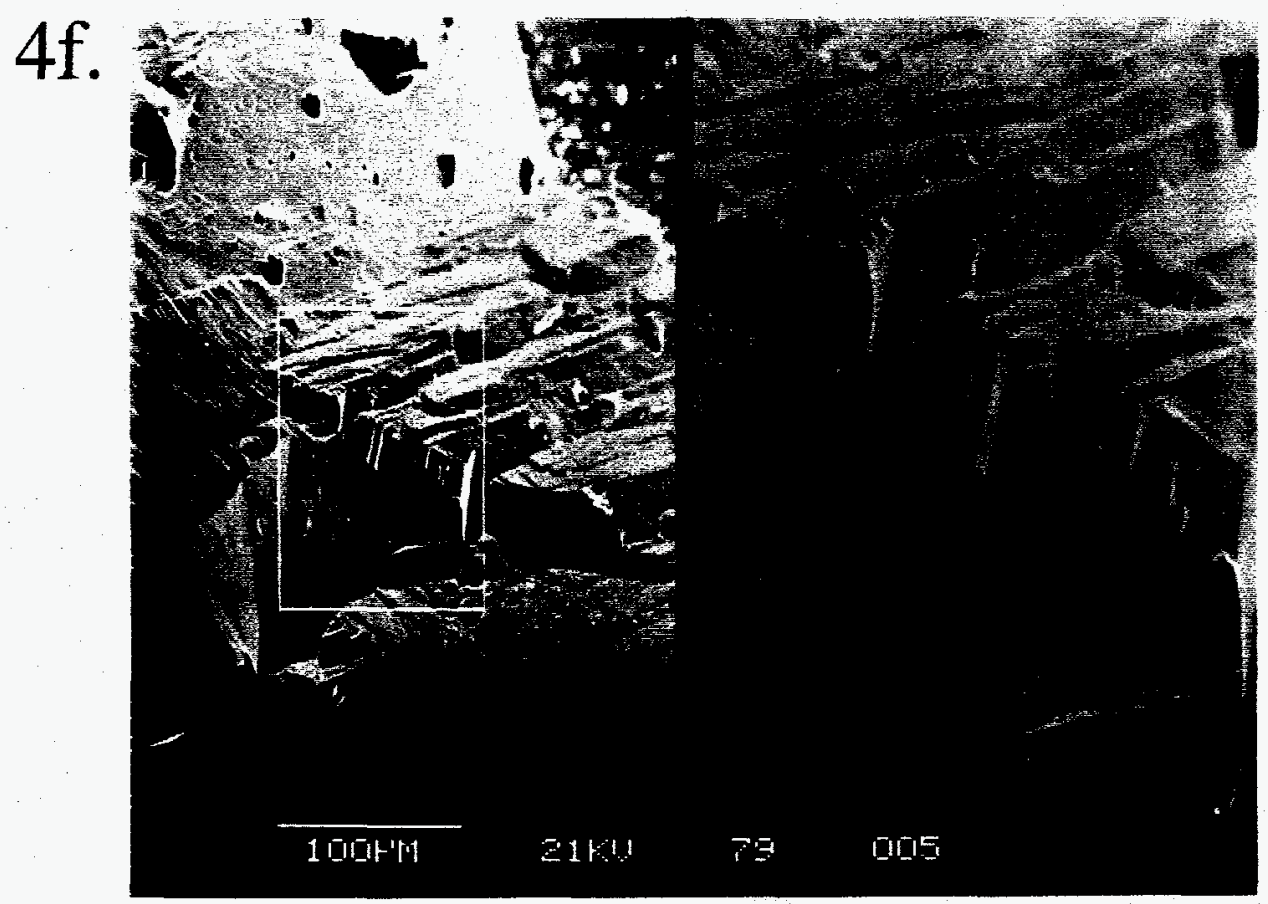

Figure 4f. Photomicrograph of a basal dissolution zone, with delicate forms representing miniature speleothems or meniscus cements. Image on right is an approximately $3 X$ enlargement. Scale bar indicates 100 microns. 
'suodolu ot sajeolpul deq ejeos 'aoejuns

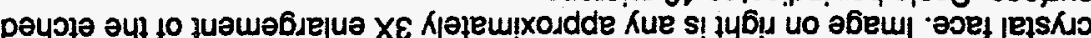

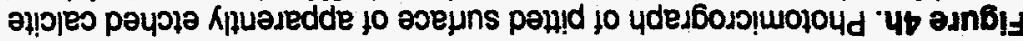

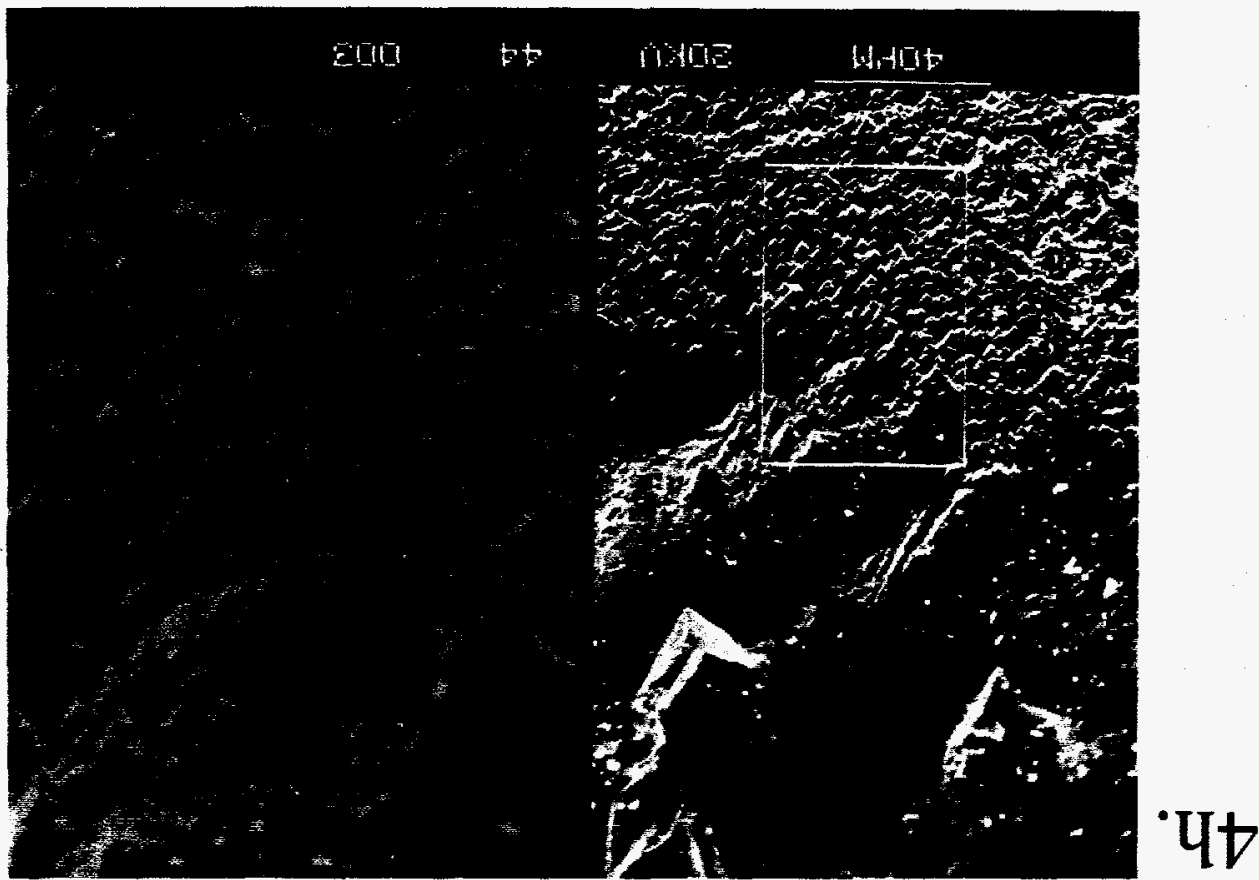

'suodo!̣ 002 sə1eo!̣pu! jeq ә|еos 'saouaunoso әsaul u!

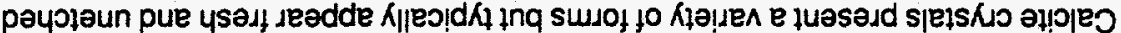

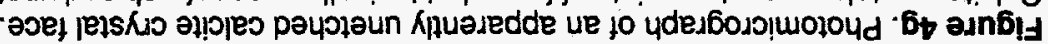

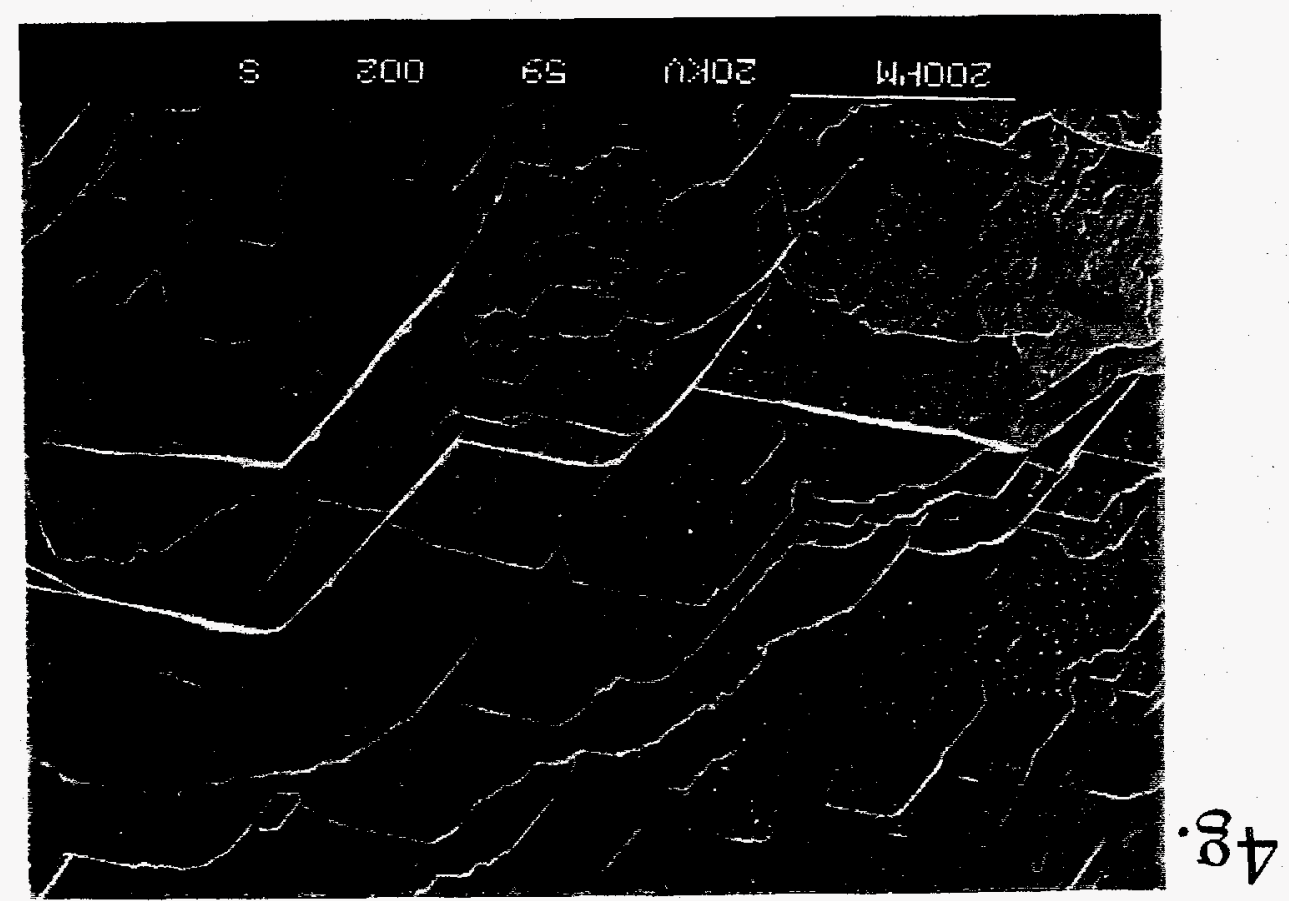


The generalizations discussed here and the specifics listed in appendix 1 are preliminary. Further petrographic and scanning-electron microscopic examination of samples collected during completion of the ESF might provide additional textural constraints that would clarify the hydrologic and geochemical histories of calcite and opal deposition.

\section{ISOTOPIC DATA}

Determinations of the $\delta^{13} \mathrm{C}$ and $\delta^{18} \mathrm{O}$ of 310 secondary calcite samples from ESF occurrences and 123 determinations from drill-core occurrences were performed to obtain isotopic characterizations of the secondary calcite (appendix 2). These measurements supplement data from previously published reports (Whelan and Stuckless, 1992; Whelan and others, 1994; Whelan and Moscati, U.S. Geological Survey, written commun., 1997) and are merged with those data on figures 5 and 6. Isotopic data obtained from samples taken from ESF occurrences located between the northern portal and station 40 are listed in appendix 2. Calcite from those ESF occurrences has $\delta^{33} \mathrm{C}$ values ranging from -9 to +8.4 per mil and $\delta^{18} \mathrm{O}$ values ranging from 10.5 to 20.6 per mil (fig. 6). Preliminary determinations of the ${ }^{87} \mathrm{Sr} /{ }^{86} \mathrm{Sr}$ ratio of ESF calcite from occurrences near stations 5, 14, 16, 17,19 , and 30 ranged from 0.70958 to 0.71250 .

\section{Implications of new Exploratory Studies Facility data to previous interpretations}

Carbon isotopic compositions of unsaturatedzone calcite reflect exchange between infiltrating fluids and components of the overlying soils and are fundamentally controlled by variations in the proportions of $\mathrm{C} 3$ and $\mathrm{C} 4$ plants that comprise the surface plant community and which vary as a function of climate. Plants photosynthesize via two pathways, designated $\mathrm{C} 3$ and $\mathrm{C} 4$, which result in markedly different carbon isotopic compositions of about 26 and -13 per mil, respectively (see, for example, Quade and others, 1989). The C4 plants (such as many grasses) favor drier and hotter climates and are better suited to handle those climatic stresses, whereas wetter and milder climates promote growth of woody, herbaceous $\mathrm{C} 3$ plants. The isotopic compositions of soil organic matter and respired $\mathrm{CO}_{2}$ in the soil are, therefore, closely related to climate, and the $\delta^{13} \mathrm{C}$ values of dissolved carbonate in unsaturated-zone percolation (and the calcite formed from it) are a reflection of the climate at the time of infiltration. Oxygen isotopic compositions of unsaturated-zone calcite record the $\delta^{18} \mathrm{O}$ of contemporaneous meteoric waters. The newly obtained $\delta^{13} \mathrm{C}$ and $\delta^{18} \mathrm{O}$ values shown in figures 5 and 6 and tabulated in appendix 2 support the conclusions of Whelan and Stuckless (1992) that unsaturated-zone secondary mineralization formed in a vadose setting, largely from percolation of surface infiltration and at near present-day ambient temperatures. The new data reported here, however, demonstrate a much wider distribution of paragenetically early calcite than previous studies of drill-core occurrences had revealed. The early calcite has higher $\delta^{13} \mathrm{C}$ values that are incompatible with the carbon isotopic compositions of soil-exchanged percolation.

\section{Carbon-13-enriched calcite from the Exploratory Studies Facility}

Local occurrences of early calcite from drillcore samples display atypically heavy $\left({ }^{13} \mathrm{C}\right.$-enriched) $\delta^{13} \mathrm{C}$ values (fig. 5). Those occurrences (Whelan and Moscati, U.S. Geological Survey, written commun., 1997) also display $\delta^{18} \mathrm{O}$ values that decrease more rapidly with depth, indicating that this early calcite was deposited at warmer temperatures and possibly was subject to a steeper geothermal gradient than prevailed during the formation of later, percolationdeposited calcite.

Exploratory Studies Facility calcite occurrences (fig. 6) more commonly display $\delta^{13} \mathrm{C}$ values greater than 0 per mil than had been observed in drill-core occurrences (fig. 5). Most of that ${ }^{13} \mathrm{C}$-enriched calcite occurs within the upper half of the Topopah Spring Tuff. Because it is possible to examine and select the most paragenetically complete assemblages when sampling in the ESF, in contrast to the random set of occurrence intersections from drill core, the increased representation of ${ }^{13} \mathrm{C}$-enriched calcite in the ESF data set could reflect a sampling bias. However, it could as well indicate a real difference between the early hydrologic history of the Topopah Spring Tuff and the other unsaturated zone tuffs. The ${ }^{13} \mathrm{C}$-enriched calcite is much more common in the non-lithophysal zones than in the upper lithophysal zone of the Topopah Spring Tuff (fig. 6), although the cause of this apparent lithologic control is not clear. 


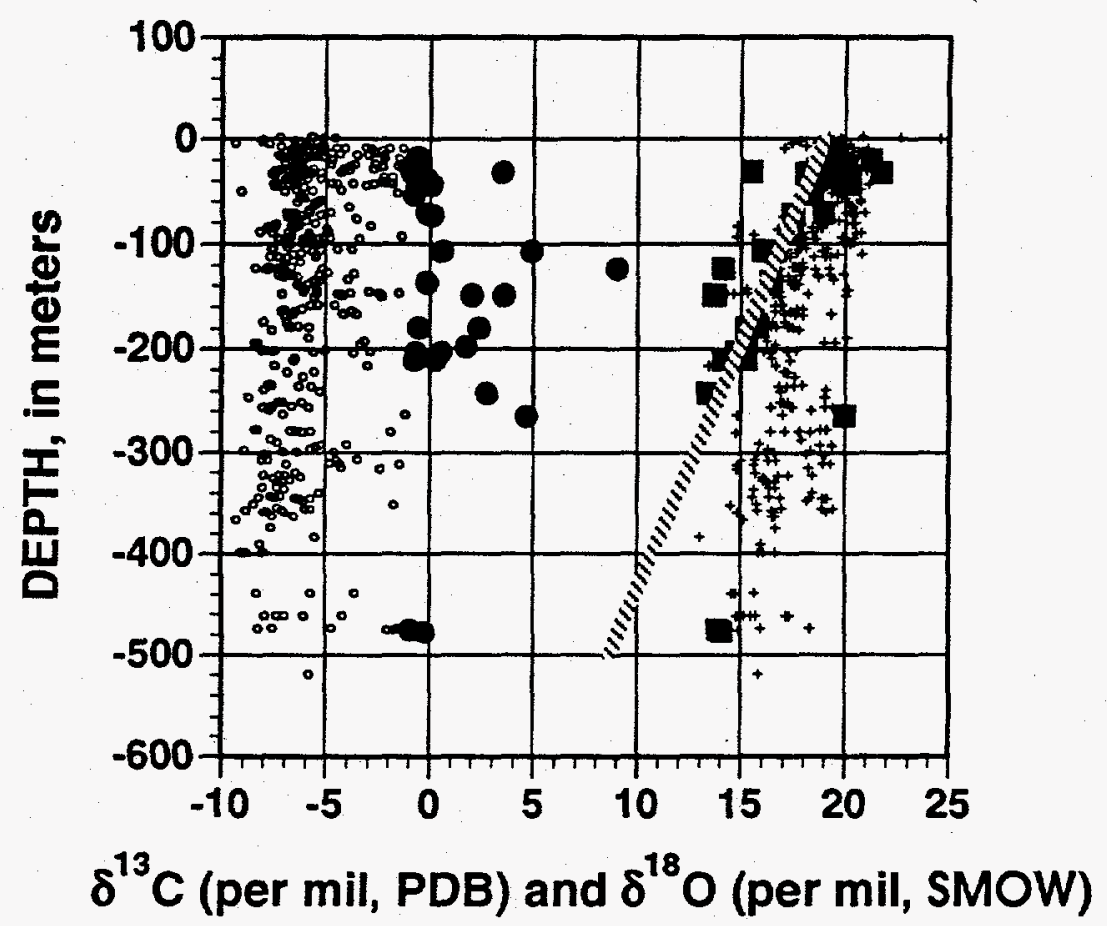

Figure 5. Distribution of unsaturated-zone $\delta^{13} \mathrm{C}$ (o symbol) and $\delta^{18} \mathrm{O}$ (+ symbol) values of calcite plotted against depth (in meters). Occurrences of ${ }^{13} \mathrm{C}$-enriched paragenetically early calcite are designated by $\left(\delta^{13} \mathrm{C}\right)$ and $\left(\delta^{18} \mathrm{O}\right)$ symbols. The hatched line shows the predicted $\delta^{18} \mathrm{O}$ of calcite precipitated along a hypothetical geothermal gradient of approximately $100^{\circ}$ $\mathrm{C} / \mathrm{km}$ trom a fluid with a $\delta^{18} \mathrm{O}$ of approximately -12.5 per mil.

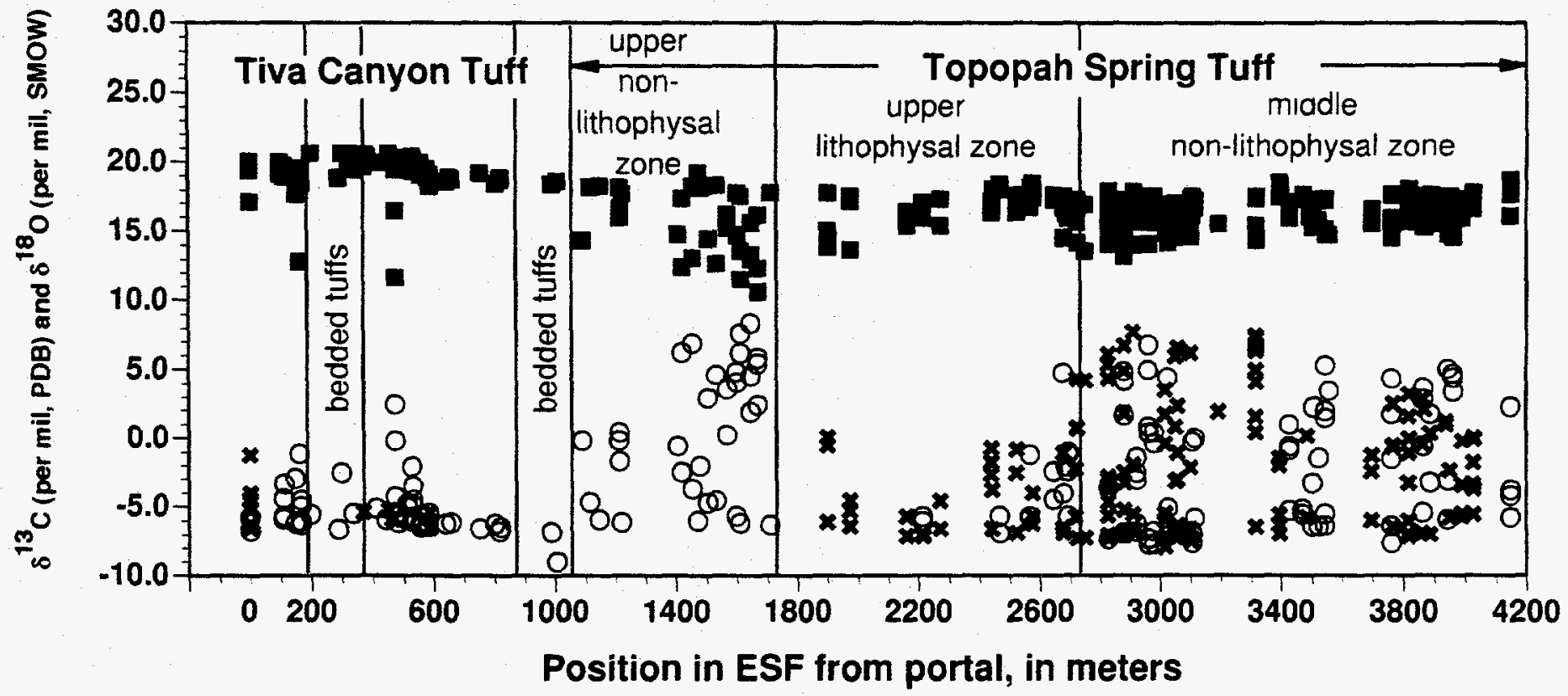

Figure 6. Graph showing $\delta^{13} \mathrm{C}$ and $\delta^{18} \mathrm{O}$ values of Exploratory StudiesFacility calcite samples plotted against distance from the portal (station 000$)$. $\delta^{18} \mathrm{O}$ values of all calcite are plotted as $=\delta^{13} \mathrm{C}$ values of a calcite from lithophysal cavities and from fracture coatings are plotted as $X$ and $O$, respectively.

14 Applicatlons of Isotope Geochemistry to the Reconstruction of Yucca Mountain, Nevada, Paleohydrology-Status of Investigations: June 1996 
Provisional measurements of the ${ }^{87} \mathrm{Sr} /{ }^{86} \mathrm{Sr}$ ratios of ESF calcite samples ( 20 analyses) provide further insight into the origin of the paragenetically early ${ }^{13} \mathrm{C}$-enriched calcite. Peterman and others (1992) and Marshall and others (1993) concluded that most of the secondary calcite in the unsaturated zone reflects pedogenic strontium sources which have an average ${ }^{87} \mathrm{Sr} /{ }^{86} \mathrm{Sr}$ ratio of 0.71215 . Unsaturated-zone calcite occurrences just above the water table, however, had strontium isotopic compositions (average ${ }^{87} \mathrm{Sr} /{ }^{86} \mathrm{Sr}$ value of 0.70909) indicating addition of less-radiogenic strontium, perhaps from the saturated zone. Saturated-zone calcite ${ }^{87} \mathrm{Sr} /{ }^{86} \mathrm{Sr}$ ratios are compatible with derivation of strontium either from the host tuffs of Yucca Mountain or from underlying Paleozoic marine carbonate rocks during an incursion of heated Paleozoic-aquifer water (Marshall and others, 1992), possibly during formation of the Timber Mountain caldera (Broxton and others, 1987; Bish and Aronson, 1993).

Paragenetically early calcite has less-radiogenic ${ }^{87} \mathrm{Sr} /{ }^{86} \mathrm{Sr}$, higher $\delta^{13} \mathrm{C}$, and lower $\delta^{18} \mathrm{O}$, whereas paragenetically later calcite exhibits more-radiogenic ${ }^{87} \mathrm{Sr} /{ }^{86} \mathrm{Sr}$, lower $\delta^{13} \mathrm{C}$, and relatively higher $\delta^{18} \mathrm{O}$ (figs. 7a and b). Whether these trends reflect a continuum of ${ }^{87} \mathrm{Sr} /{ }^{86} \mathrm{Sr}$ ratios, or mixtures of early and late calcite created mechanically during sampling, is not yet clear. It is clear, however, that the less-radiogenic ${ }^{87} \mathrm{Sr} /{ }^{86} \mathrm{Sr}$ ratios may indicate a tuffaceous strontium source for the early calcite as opposed to the more radiogenic pedogenic calcite that appears to provide strontium for the later unsaturated-zone calcite. Furthermore, the rapid decrease of early calcite $\delta^{18} \mathrm{O}$ values with depth indicates a steeper geothermal gradient and warmer fluid temperatures (fig. 5). Both of the above observations are compatible with calcite deposition closely following eruptive activity, when geothermal gradients may have been higher and calcareous soils had not yet formed. Although these preliminary data indicate a distinctly different geochemical environment for the paragenetically early calcite, the distribution of that calcite is still spatially restricted to the footwalls of fractures and the floors of lithophysae. Therefore, other differences aside, the earliest and oldest calcite present in these samples still indicate formation under unsaturated conditions.

\section{Silica-phase oxygen isotope studies}

Silica minerals occur throughout the paragenesis. Tridymite formed as a vapor-phase mineral within lithophysal cavities and along cooling joints during initial cooling and outgassing of the tuffs. Chalcedony (cryptocrystalline quartz) and both drusy and coarse euhedral quartz appeared early and generally preceded calcite deposition, whereas opal occurs sporadically within and upon later calcite as laminated coats, botryoidal masses, or isolated hemispherical grains.

The fractionation of ${ }^{18} \mathrm{O}$ between a silica mineral and the mineralizing fluid is determined by temperature; $\delta^{18} \mathrm{O}$ values can be used, therefore, to infer the formation temperatures of such minerals. Histograms of the $\delta^{18} \mathrm{O}$ values of the various silica phases sampled from Yucca Mountain drill cores and outcroppings (appendix 3) display increasing $\delta^{18} \mathrm{O}$ with decreasing temperature (fig. 8). Tridymite $\delta^{18} \mathrm{O}$ values record deposition at high, nearly syn-volcanic, temperatures and low water-to-rock ratios, with $\delta^{18} \mathrm{O}$ values in the range 9 to 17 per mil. Chalcedony, the earliest post-vapor-phase mineral in many occurrences, has $\delta^{18} \mathrm{O}$ values ranging from 5.8 to 17.3 per mil. Quartz, occurring both as early drusy crusts within and upon the chalcedony and as sprays of clear, inclusion-free prismatic crystals as long as $1 \mathrm{~cm}$, has $\delta^{18} \mathrm{O}$ values ranging from 8.6 to nearly 24 per mil. Higher water temperatures are required by the lowest $\delta^{18} \mathrm{O}$ values of both the chalcedony and quartz, likely greater than $120^{\circ} \mathrm{C}^{1}$ (Moscati and Whelan, 1996). Such temperatures are consistent with formation either

\footnotetext{
1. There are no independent constraints on the temperatures of any unsaturated-zone fluids except fluid inclusion studies of late calcite suggesting formation temperatures less than $100^{\circ} \mathrm{C}$ (Roedder and others, 1994). A fluid $\delta^{18} \mathrm{O}$ of -12.5 per mil is assumed only to permit qualitative comparison of the $\delta^{18} \mathrm{O}$ values of the different silica phases. At cooler temperatures, this is a reasonable assumption, although the $\delta^{18} \mathrm{O}$ of percolation has likely varied by at least \pm 2 per mil around this value. At higher temperatures, water exchanges ${ }^{18} \mathrm{O}$ with the rocks that it passes through which results in increased water $\delta^{18} \mathrm{O}$ values. The amount of the increase will be a function of the temperature and the waterto-rock ratio; assuming a value of -12.5 per mil for the heated water produces minimum calculated mineral-formation temperatures. Clayton and others (1972) and Kita and others (1985) are the respective sources of the quartz (and chalcedony) $-\mathrm{H}_{2} \mathrm{O}$ and opal- $\mathrm{H}_{2} \mathrm{O}$ fractionation factors used to determine formation temperatures.
} 


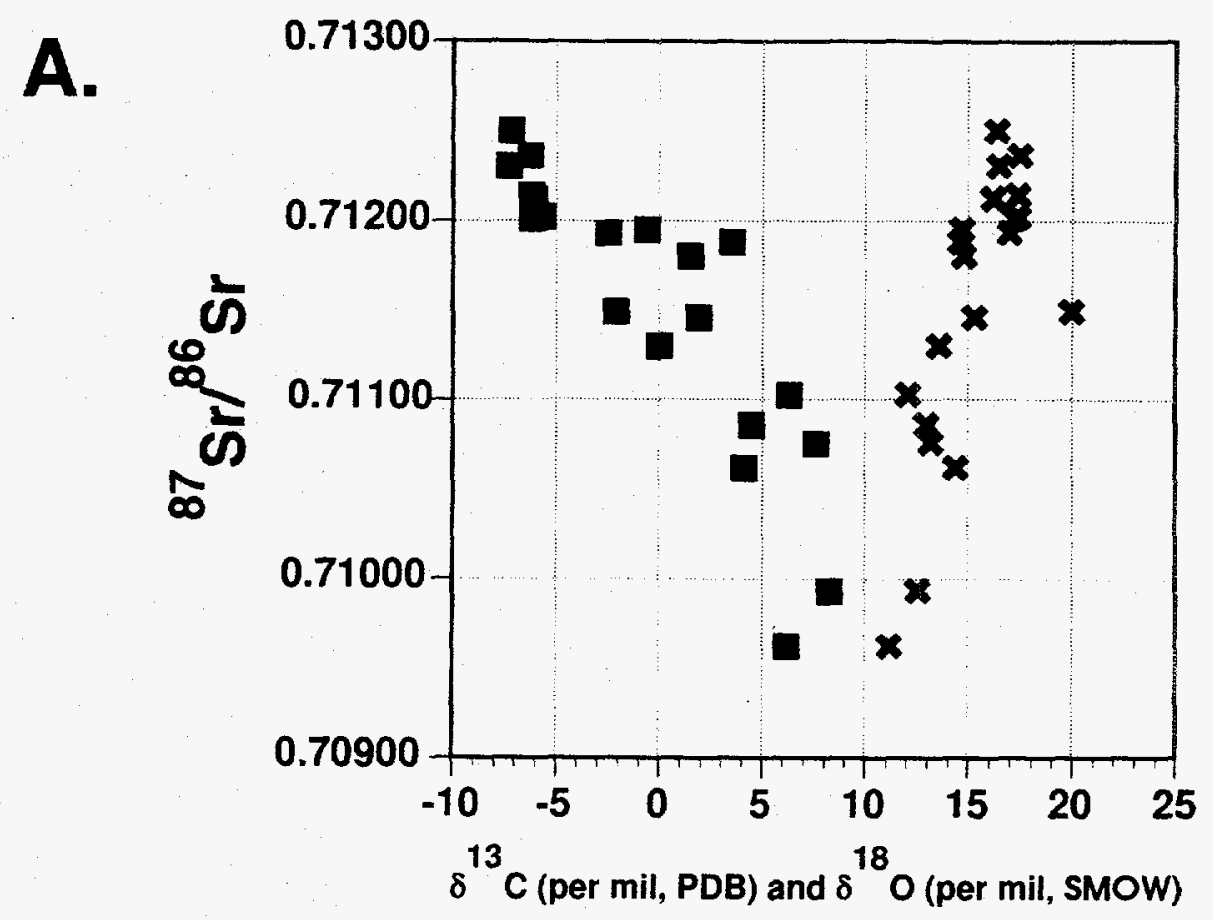

B.

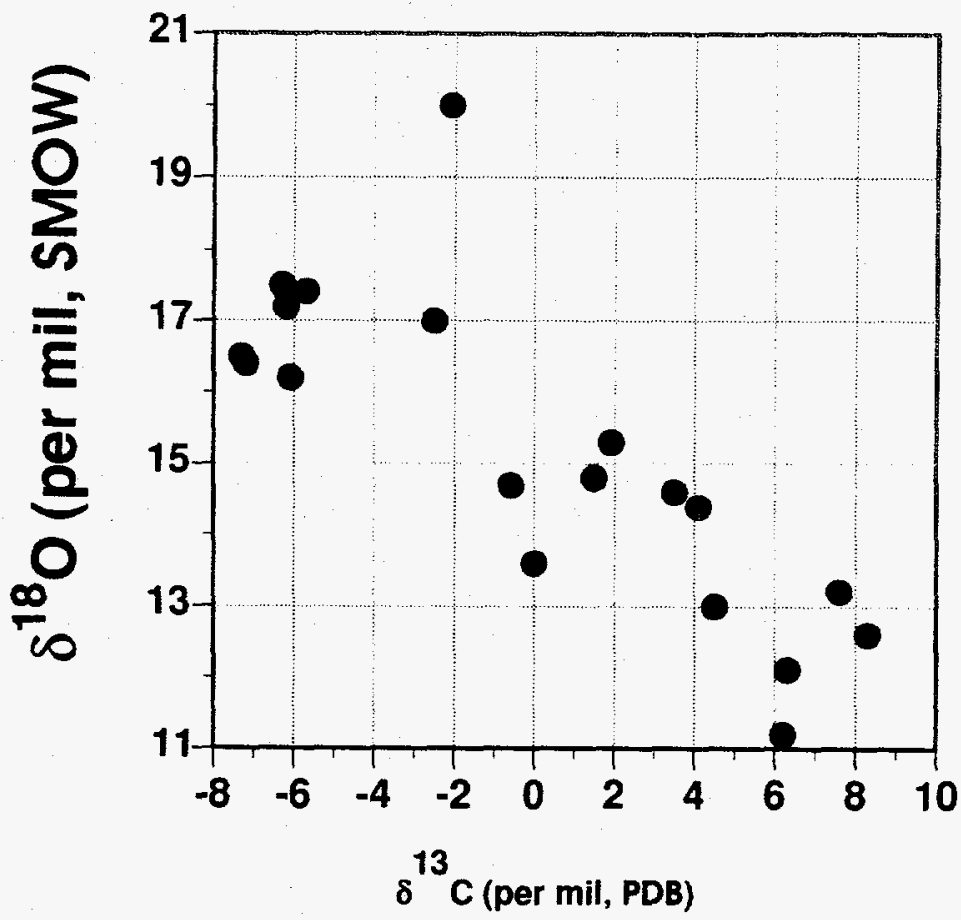

Figure 7. Preliminary radiogenic Sr isotopic compositions plotted against the $\delta^{13} \mathrm{C}(\mathrm{C})$ and $\delta^{18} \mathrm{O}(\mathrm{X})$ isotopic compositions of the Exploratory Studies Facility (ESF) calcite (A), and the correlation between $\delta^{13} \mathrm{C}$ and $\delta^{18} \mathrm{O}$ values of the same ESF calcite

$(\bullet)$, shown in (B). In general, larger $\delta^{13} \mathrm{C}$ values correlate with older occurrences. 

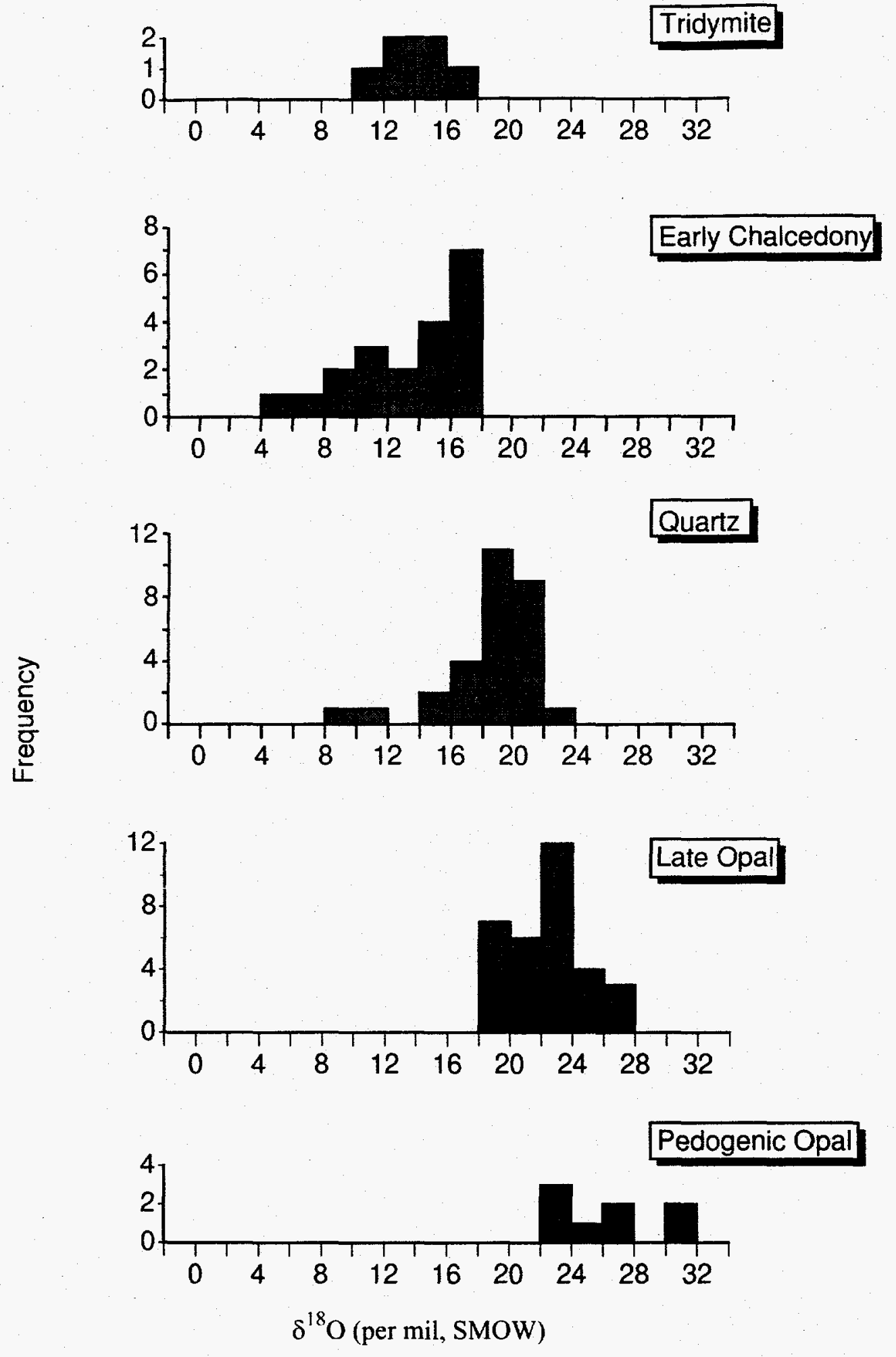

Figure 8. Histograms of Yucca Mountain unsaturated zone secondary silica $\delta^{18} \mathrm{O}$ (per mil, SMOW) values. Relative temperatures of formation and relative ages of silica phases decrease from top to bottom of the figure. 
before the host tuff had cooled, or during a later thermal pulse, perhaps accompanying eruption of some of the younger units. Chalcedony and quartz $\delta^{18} \mathrm{O}$ values in the middle part of the observed range require either water temperatures slightly warmer $\left(60\right.$ to $70^{\circ} \mathrm{C}$ ) or water $\delta^{18} \mathrm{O}$ values somewhat lower (about 2 per mil) than occur in the unsaturated zone today, whereas the highest quartz $\delta^{18} \mathrm{O}$ values are compatible with present-day water $\delta^{18} \mathrm{O}$ values and temperatures.

Silica mineralization records a wide range of depositional conditions and possibly long depositional history, as well. Whether silica phases also have recorded climatic variability is problematic. Silica phases might have been, occasionally, the dominant secondary minerals forming from percolation, perhaps during times or climates when overlying soils were thin or absent and percolating fluids were deprived of that important source of calcium and carbon for calcite formation.

Opal is the latest silica phase in the unsaturated zone, generally occurring only with calcite. Late opal has $\delta^{18} \mathrm{O}$ values ranging from 18.0 to 27.9 per mil and, assuming water of -12.5 per mil, formed at temperatures of 7 to $45^{\circ} \mathrm{C}$ (Moscati and Whelan, 1996).

Temperatures in the lower part of this range are unlikely. Past variability in $\delta^{18} \mathrm{O}$ values of meteoric water and (or) percolation probably contributed to the relatively large range of opal $\delta^{18} \mathrm{O}$ values.

Pedogenic opal from the overlying soils has the highest $\delta^{18} \mathrm{O}$ values, ranging from 22 to nearly 32 per mil. Assumption of a water $\delta^{18} \mathrm{O}$ value of -12.5 per mil produces estimates that the pedogenic opal formed at temperatures ranging from about $30^{\circ} \mathrm{C}$ down to an improbable $-3^{\circ} \mathrm{C}$. Such low estimated temperatures indicate that the opal with the highest $\delta^{18} \mathrm{O}$ values likely was formed from waters with $\delta^{18} \mathrm{O}$ values higher than -12.5 per mil. The ${ }^{18} \mathrm{O}$ enriched waters might reflect warmer and (or) wetter climates, or evaporative enrichment of the water precipitating pedogenic opal (Moscati and Whelan, 1996).

Silica-mineral $\delta^{18} \mathrm{O}$ values increase from early to late in the paragenetic sequence, implying an overall decrease of depositional temperatures with time. In addition, with the lowest calculated formation temperatures occurring within the overlying soils, opal $\delta^{18} \mathrm{O}$ values conform to increasing temperatures with depth in the unsaturated zone. Some of the early chalcedony and drusy quartz seem to have formed at somewhat elevated temperatures. Combined with their early position in the paragenesis, this indicates that they formed before the tuffs had completely cooled. Later quartz euhedra, however, appear seem to have formed at temperatures compatible with the modern geotherm and climate; their water-clear, inclusion-free crystallinity and euhedral habit are consistent with slow growth from relatively cool fluids.

\section{Radiocarbon geochronologic studies}

The timing of latest calcite formation in ESF occurrences is being studied with ${ }^{14} \mathrm{C}$ and ${ }^{230} \mathrm{Th} / \mathrm{U}$ geochronometers. Carbon-14 age determinations can be performed on far smaller amounts of calcite than can the ${ }^{230} \mathrm{Th} / \mathrm{U}$ method, an advantage that permits greater sampling resolution. Calcite ${ }^{14} \mathrm{C}$ contents, however, may be susceptible to post-depositional contamination from modern carbon sources such as carbon-bearing fluids or gases in the unsaturated zone. Carbon-14 decays with a half-life of about 5730 years. Although the analytical precision of accelerator mass spectrometry (AMS) is excellent, age determinations begin to lose credibility at ages about $40 \mathrm{ka}$. At that age, over $99 \%$ of the initial ${ }^{14} \mathrm{C}$ has decayed, and minimal contamination by modern ${ }^{14} \mathrm{C}$ can seriously compromise age determinations, especially from small (10- to $30-\mathrm{mg}$ ) samples.

Past studies have demonstrated that percolating fluids in the unsaturated zone at Yucca Mountain obtain their $\delta^{13} \mathrm{C}$ signature largely through interaction with carbonate and organic matter in the overlying soils (for example, Whelan and others, 1994). This interaction is characterized by the reaction

$$
\mathrm{CaCO}_{3}+\mathrm{CO}_{2}+\mathrm{H}_{2} \mathrm{O} \longleftrightarrow 2 \mathrm{HCO}_{3}^{-}+\mathrm{Ca}^{2+}
$$

in which, as $\mathrm{CO}_{2}$ is taken into solution, calcite is dissolved. The $\mathrm{CO}_{2}$, derived primarily from the oxidation of soil organic matter but secondarily from diffusion of atmospheric gases, is near 100 percent modern carbon ( $\mathrm{pmc}$ ). The calcite dissolved according to equation 2 , however, may be old and have 0 pmc ("dead" $\mathrm{C}$ ), and the $\mathrm{HCO}_{3}{ }^{-}$of the resulting solution could have a ${ }^{14} \mathrm{C}$ content as low as $50 \mathrm{pmc}$; infiltrating 
waters could, therefore, have an initial ${ }^{14} \mathrm{C}$ age of one half-life, or about 5700 years. It is unlikely, therefore, that either percolating waters, or calcite precipitated from them in the unsaturated zone, ever record the correct timing of infiltration. Furthermore, the ${ }^{14} \mathrm{C}$ clock for secondary calcite is not set until the calcite is precipitated, so estimates of the timing of infiltration must be adjusted for the travel time of the percolation to the site of deposition.

An ancillary undertaking is to evaluate the likelihood of exchange between the outer surfaces of secondary calcite crystals and later, ${ }^{14} \mathrm{C}$-bearing, gases and fluids in the unsaturated zone. Such exchange might create a ${ }^{14} \mathrm{C}$-enriched outer layer on the calcite crystals and, therefore, a young age bias in the ${ }^{14} \mathrm{C}$ data. To test this possibility, the crystal faces of freegrowing calcite from several samples were etched briefly with dilute $\mathrm{HCl}$ to remove the outer surface. Those etched surfaces were then sampled, as were comparable unetched free-growth calcite surfaces from the occurrence. A minimal difference between these paired ${ }^{14} \mathrm{C}$ age determinations might indicate that post-depositional interaction with rock gases is not a concern. A large difference would be compatible with a thin surface layer of ${ }^{14} \mathrm{C}$-contaminated calcite on a ${ }^{14} \mathrm{C}$-"dead" substrate; such a relationship would also, however, be in accord with extremely low calcite depositional rates and most of the ${ }^{14} \mathrm{C}$-datable calcite record having been removed by the acid etching. This is a moot point, however, in that if calcite depositional rates are that low, then calculated ${ }^{14} \mathrm{C}$ ages are probably unrealistic anyway.

In spite of the stated caveats, ${ }^{14} \mathrm{C}$ dating of calcite still offers useful constraints on the history of percolation flux in the unsaturated zone, primarily because, in many of the occurrences, calcite was the last or only mineral formed. (This is especially true for the fracture occurrences.) Furthermore, because ages can be determined from calcite subsamples as small as $10 \mathrm{mg},{ }^{14} \mathrm{C}$ permits finer-scale sampling and, therefore, better age resolution of calcite formation than can other dating techniques.
To date, subsamples submitted for ${ }^{14} \mathrm{C}$ AMS age determination have come from (1) the latest surfaces of free-growth calcite crystals or (2) the basal zones of calcite dissolution present in many samples. All of the subsamples from zones of basal dissolution contain a mixture of the "late" overgrowths and the residual, possibly ${ }^{14} \mathrm{C}$-dead, calcite substrate. These subsamples should still provide an indication, however, of whether a given dissolution event occurred within the past $40 \mathrm{ka}$, and the subsamples are therefore significant for reconstruction of hydrology/climate interactions in the recent past.

Provisional results of the ${ }^{14} \mathrm{C}$ geochronometry indicate calculated ${ }^{14} \mathrm{C}$ ages (radiocarbon years) in a range from greater than $16 \mathrm{ka}$ to about $42 \mathrm{ka} \mathrm{(fig.} \mathrm{9).} \mathrm{A}$ significant percentage of the samples showed calculated ages less than $32 \mathrm{ka}$, indicating a significant component of modern carbon. This relation implies that much of the secondary calcite sampled in the ESF contains at least thin layers deposited during or since the last glacial cycle, and that calcite ${ }^{14} \mathrm{C}$ measurements provide at least a relative tool for spatial and temporal mapping of percolation pathways within the unsaturated zone at Yucca Mountain.

None of the data (shown in appendix 3 and fig. 8) discussed here tested the possibility of surfacelayer ${ }^{14} \mathrm{C}$ contamination in ESF samples. Samples of thick mammillary calcite crusts, however, collected from the unsaturated zone of the Sterling Mine on Bare Mountain (fig. 1) west of Yucca Mountain, were tested. Opposite halves of a sawn specimen were ground and polished to reveal the growth banding. One half was briefly etched in dilute $(0.2 \mathrm{~N}) \mathrm{HCl}$, then both were washed ultrasonically in deionized water, and the youngest band of calcite was milled from each half. The acid-etched sample had an apparent ${ }^{14} \mathrm{C}$ age of $15.3 \pm 0.12 \mathrm{ka}$, whereas the unetched sample gave an age of $14.7 \pm 0.12 \mathrm{ka}$. The minimal difference between the two ages provides little support for post-depositional exchange between modern carbon and unsaturated-zone gases or fluids during the past $15 \mathrm{ky}$, at least at Bare Mountain. 


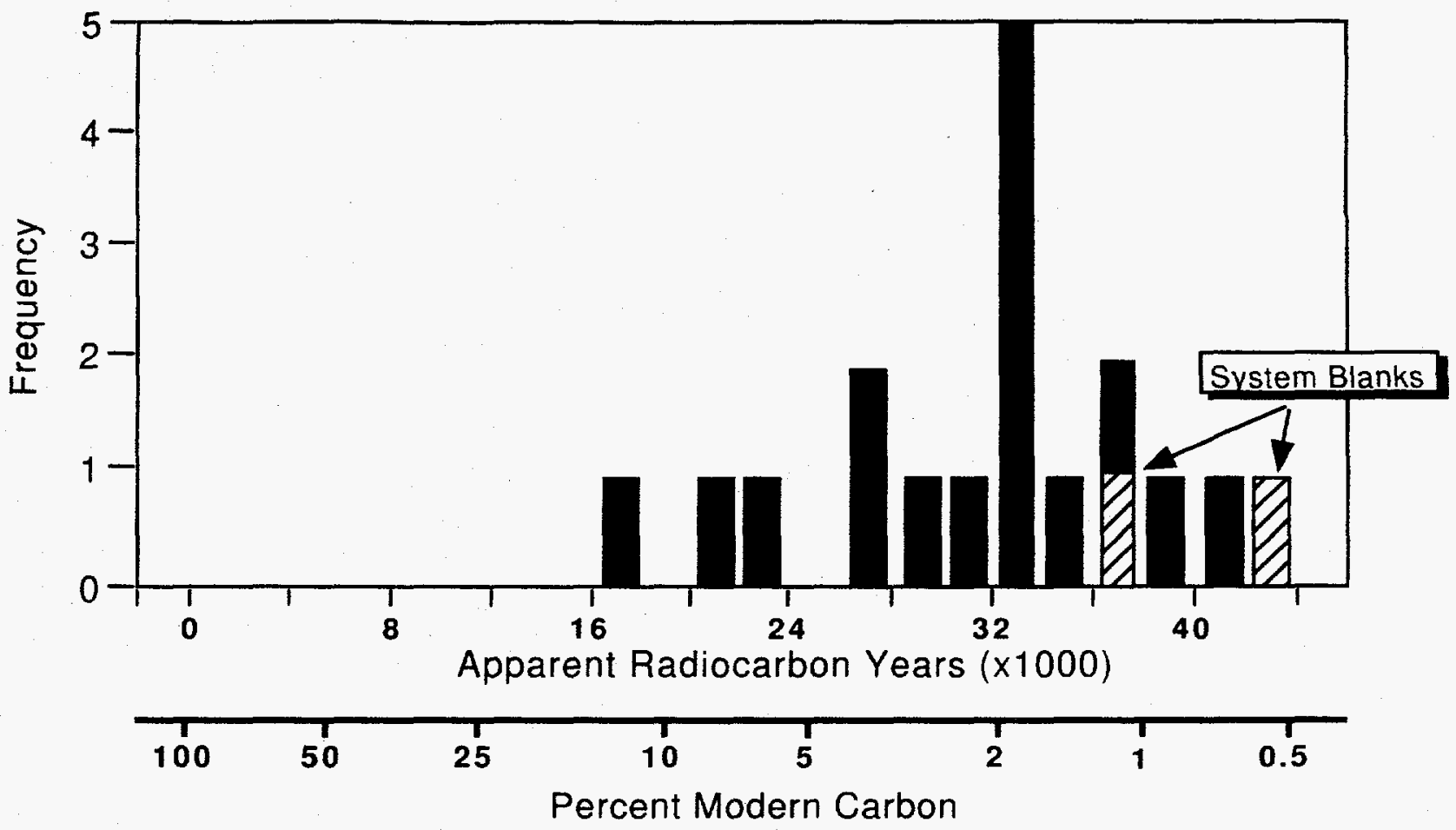

Figure 9. Histogram showing the distribution of ${ }^{14} \mathrm{C}$ ages from the Exploratory Studies Facility calcite occurrences. Upper $\mathrm{x}$-axis shows the apparent age calculated from measured percentages of modern carbon in the sample; no attempt was made to correct for incorporation of dead carbon or ground-water travel time. Lower $x$-axis displays the relationship between percent modern carbon and apparent age, and underscores the large error that trace amounts of ${ }^{14} \mathrm{C}$ contamination cause in older materials. System blanks are the amounts of ${ }^{14} \mathrm{C}$ measured in samples of Paleozoic calcitic marble subjected to the entire extraction and Accelerator Mass Spectrometer analysis process. 


\section{CONCLUSIONS}

1. Post-vapor-phase secondary mineralization in the unsaturated zone consisted of an early stage dominated by silica deposition, locally with coeval or possibly precursor calcite, followed by main-stage calcite and opal. Main-stage mineralization, as defined herein, groups all early-stage calcite and opal deposition. This is probably a simplification, and further study might reveal a more complex depositional history.

2. Early calcite is characterized by heavy $\delta^{13} \mathrm{C}$ values and $\delta^{18} \mathrm{O}$ values that increase more rapidly with depth than those of main-stage calcite. Coupled with its association with formation of early chalcedony and quartz, this relation may indicate that the early calcite formed at somewhat higher temperatures than the main-stage calcite and that early calcite should not be included in estimates of past percolation fluxes based on the secondary mineral record.

3. Preliminary strontium isotope analyses indicate that the early calcite contains less- radiogenic strontium than does the main-stage calcite. Rather than a pedogenic strontium source as is the case for the main stage, the tuffs themselves may have been the source of strontium in the early calcite.

4. Delta- ${ }^{18} \mathrm{O}$ values of the silica phases quartz, chalcedony, and opal indicate that some of the early massive-silica-stage phases must have formed from heated water, although parts of the massive-silica stage are compatible with modern or near-modern rock temperatures. Opal $\delta^{18} \mathrm{O}$ values argue that evaporative processes increased the $\delta^{18} \mathrm{O}$ of the precipitating water in the soil zone.

5. Preliminary radiocarbon age determinations argue that in situ interactions with later carbon-bearing water and gases have not significantly altered the

${ }^{14} \mathrm{C}$ ages of the calcite. Radiocarbon ages of the latest calcite in many of the occurrences may indicate relatively recent formation of the outermost calcite layers.

\section{REFERENCES CITED}

Bish, D.L. and Aronson, J.L., 1993, Paleogeothermal and paleohydrologic conditions in silicic tuff from Yucca Mountain, Nevada: Clays and Clay Minerals, v. 41, no. 2, p. 148-161.
Broxton, D.E., Bish, D.L., and Warren, R.G., 1987, Distribution and chemistry of diagenetic minerals at Yucca Mountain, Nye County, Nevada: Clays and Clay Minerals, v. 35, no. 2, p. 89-110.

Buesch, D.C., Spengler, R.W., Moyer, T.C., and Geslin, J.K., 1996, Revised stratigraphic nomenclature and macroscopic identification of lithostratigraphic units of the Paintbrush Group exposed at Yucca Mountain, Nevada: U.S. Geological Survey Open-File Report 94-469, $47 \mathrm{p}$.

Byers, F.M., Jr., Carr, W.J., Orkild, P.P., Quinlivan, W.D., and Sargent, K.A., 1976, Volcanic suites and related cauldrons of Timber Mountain-Oasis Valley caldera complex, southern Nevada: U.S. Geological Survey Professional Paper 919, 70 p.

Carr, W.J., 1984, Regional structural setting of Yucca Mountain, southwestern Nevada, and Late Cenozoic rates of tectonic activity in parts of the southwestern Great Basin, Nevada and California: U.S. Geological Survey Open-File Report 84-854, 109 p.

Christiansen, R.L., and Lipman, P.W., 1965, Geologic map of the Topopah Spring NW quadrangle, Nye County, Nevada: U.S. Geological Survey Geological Quadrangle Map GQ-444, scale 1:24,000.

Clayton, R.N., and Mayeda, T.K., 1963, The use of bromine pentafluoride in the extraction of oxygen from oxides and silicates for isotopic analysis: Geochimica et Cosmochimica Acta, v. 27, no. 1, p. 43-52.

Clayton, R.N., O'Neil, J.R., and Mayeda, T.K., 1972, Oxygen isotope exchange between quartz and water: Journal of Geophysical Research, v. 77, p. 3057-3067.

Gary, M., McAfee, R., Jr., and Wolf, C.L., 1974, Glossary of Geology: American Geological Institute, Washington, D.C., 805 p.

Haimson, M., and Knauth, L.P., 1983, Stepwise fluorination - A useful approach for the isotopic analysis of hydrous minerals: Cochimica et Cosmochimica Acta, v. 47 , no. 9 , p. $158 y-1595$.

Kita, I., Taguchi, S., and Matsubaya, O., 1985, Oxygen isotope fractionation between amorphous silica and water at $34-93^{\circ} \mathrm{C}$ : Nature, v. 314, no. 6006, p. $63-64$.

Marshall, B.D., Peterman, Z.E., and Stuckless, J.S., 1993, Strontium isotopic evidence for a higher water table at Yucca Mountain, in High Level Radioactive Waste Management, Proceedings of the Fourth Annual International Conference, Las Vegas, Nevada, April 26-30, 1993: LaGrange Park, Illinois, American Nuclear Society, v. 2, p. 1948-1952. 
Marshall, B.D., Whelan, J.F., Peterman, Z.E., Futa, K.F., Mahan, S.A., and Stuckless, J.S., 1992, Isotopic studies of fracture coatings at Yucca Mountain, Nevada, in Kharaka, Y.K., and Maest, A.S., eds., Proceedings of the Seventh International Symposium on Water/Rock Interaction, Park City, Utah, p. 737-740.

McCrea, J.M., 1950, The isotopic chemistry of carbonates and a paleotemperature scale: Journal of Chemical Physics, v. 18 , no. 8 , p. $849-857$.

Moscati, R.J., and Whelan, J.F., 1996, Origin of secondary silica within Yucca Mountain, Nye County, southwestern Nevada: U.S. Geological Survey Open-File Report 95-289, 14 p.

Peterman, Z.E., Stuckless, J.S., Marshall, B.D., Mahan, S.A., and Futa, K.A., 1992, Strontium isotope geochemistry of calcite fracture fillings in deep core, Yucca Mountain, Nevada a progress report, in High Level Radioactive Waste Management, Proceedings of the Third Annual International Conference, Las Vegas, Nevada, April 12-16, 1992: LaGrange Park, Illinois, American Nuclear Society, v. 2, p. 1582-1586.

Quade, Jay, Cerling, T.E., and Bowman, J.R., 1989, Systematic variations in the carbon and oxygen isotopic composition of pedogenic carbonate along elevation transects in the southern Great Basin, United States: Geological Society of America Bulletin, v. 101, no. 4, p. 464-475.

Roedder, Edwin, Whelan, J.F., and Vaniman, D.T., 1994, Fluid inclusion homogenization and crushing studies of calcite veins from Yucca Mountain, Nevada, tuffs: Environment of formation, in High-Level Radioactive Waste Management, Proceedings of the Fifth Annual International Conference, Las Vegas, Nevada, May 22-26, 1994: LaGrange Park, Illinois, American Nuclear Society, v. 4, p. $1854-1860$.

Sawyer, D.A., Fleck, R.J., Lanphere, M.A., Warren, R.G., Broxton, D.E., and Hudson, M.R., 1994, Episodic caldera volcanism in the Miocene southwestern Nevada volcanic field-revised stratigraphic framework, ${ }^{40} \mathrm{Ar} /{ }^{39} \mathrm{Ar}$ geochronology, and implications for magmatism and extension: Geological Society of America Bulletin, v. 106, p. 1304-1318.
Scott, R.B., and Bonk, Jerry, 1984, Preliminary geologic map of Yucca Mountain, Nye County, Nevada, with geologic sections: U.S. Geological Survey Open-File Report 84-494, scale 1:12,000.

Snyder, D.B., and Carr, W.J., 1984, Interpretation of gravity data in a complex volcano-tectonic setting, southwestern Nevada: Journal of Geophysical Research, v. 89, p. 10193-10206.

United States Department of Energy, 1988, Site characterization plan, Yucca Mountain site, Nevada Research and Development Area, Nevada: U.S. Department of Energy, Office of Civilian Radioactive Waste Management, document DOE/RW0199, 8 volumes.

Vaniman, D.T., and Chipera, S.J., 1996, Paleotransport of lanthanides and strontium recorded in calcite compositions from tuffs at Yucca Mountain, Nevada, USA: Geochimica et Cosmochimica Acta, v. 60, no. 22, p. 4417-4433.

Whelan, J.F., and Stuckless, J.S., 1990, Reconnaissance $\delta^{13} \mathrm{C}$ and $\delta^{18} \mathrm{O}$ data from Trench 14 , Busted Butte, and drill hole G-4, Yucca Mountain, Nevada Test Site, in High Level Radioactive Waste Management, Proceedings of the International Topical Meeting, Las Vegas, Nevada, April 8-12, 1990: LaGrange Park, Illinois, American Nuclear Society, v. 2, p. 930-934.

Whelan, J.F., and Stuckless, J.S., 1992, Paleohydrologic implications of the stable isotopic composition of secondary calcite within the Tertiary volcanic rocks of Yucca Mountain, Nevada, in High Level Radioactive Waste Management, Proceedings of the Third Annual International Conference, Las Vegas, Nevada, April 12-16, 1992: LaGrange Park, Illinois, American Nuclear Society, v. 2, p. 1572-1581.

Whelan, J.F., Vaniman, D.T., Stuckless, J.S., and Moscati, R.J., 1994, Paleoclimatic and paleohydrologic records from secondary calcite: Yucca Mountain, Nevada, in High Level Radioactive Waste Management, Proceedings of the Fifth Annual International Conference, Las Vegas, Nevada, May 22-26, 1994: LaGrange Park, Illinois, American Nuclear Society, v. 4, p. 2738-2745. 
APPENDIX 
Appendix 1. Paragenetic sequences of secondary mineral occurrences within the Exploratory Studies Facility (ESF), Yucca Mountain, Nevada

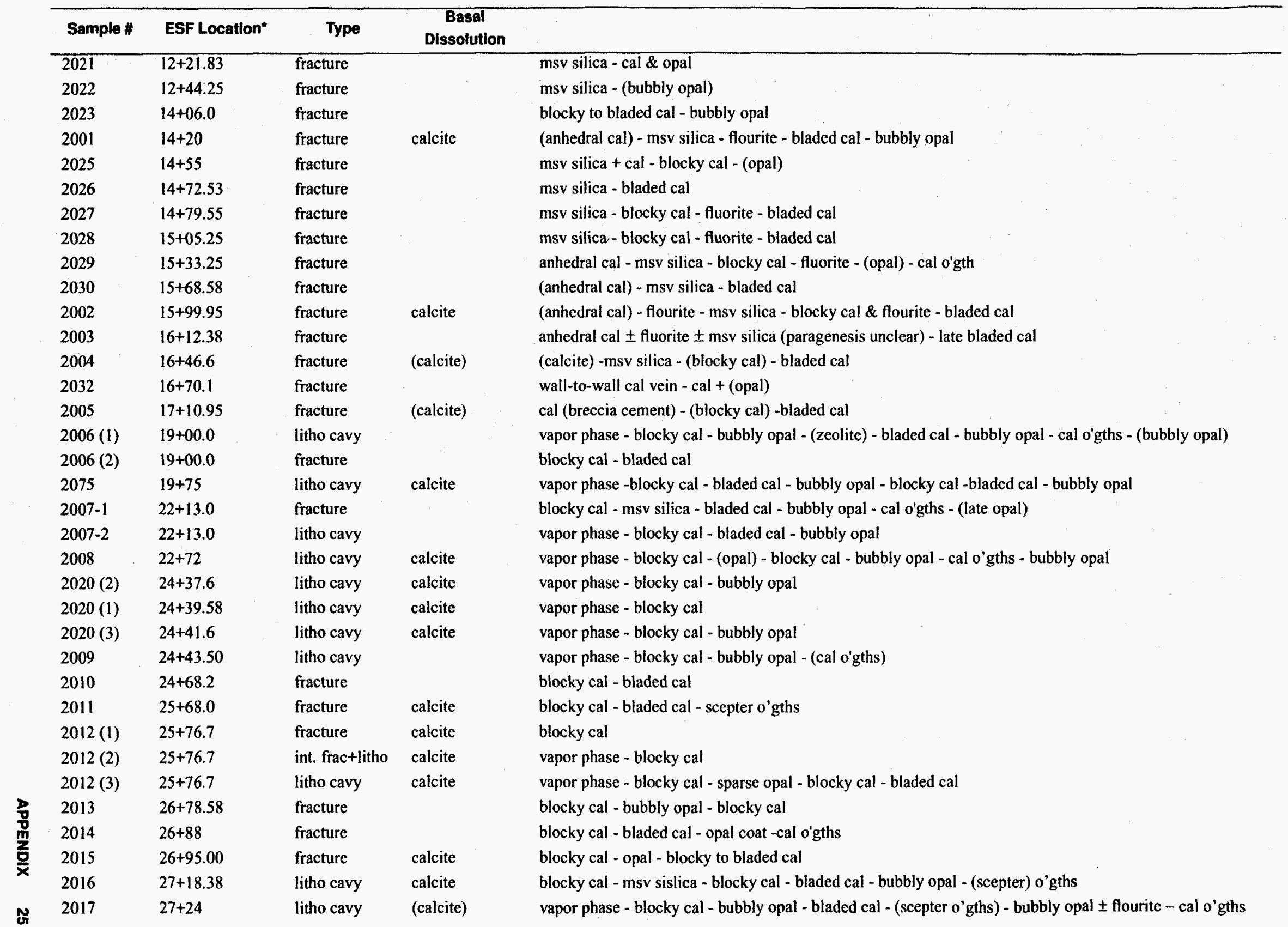


\& Appendix 1. Paragenetic sequences of secondary mineral occurrences within the Exploratory Studies Facility (ESF), Yucca Mountain, Nevada (Continued)

\begin{tabular}{|c|c|c|c|c|}
\hline Sample \# & ESF Locatlon* & Type & $\begin{array}{c}\text { Basal } \\
\text { Dissolution }\end{array}$ & \\
\hline 2018 & $27+50.65$ & litho cavy & & blocky cal - opal - bladed cal \\
\hline 2019 & $28+80$ & litho cavy & & $\begin{array}{l}\text { vapor phase - msv silica - bladed cal - botry'l opal - bladed cal - bubbly opal - multi-stage cal (incl'g scepters) } \\
+ \text { bubbly opal }\end{array}$ \\
\hline 2019 & $28+81$ & litho cavy & & $\begin{array}{l}\text { vapor phase - msv silica - bladed cal - botry'l opal - bladed cal - bubbly opal - multi-stage cal (incl'g scepters) } \\
\text { + bubbly opal }\end{array}$ \\
\hline 2054 & $28+81.6$ & fracture & & blocky cal - msv silica - bladed cal - msv silica - bladed cal - opal - zeolite - scepter o'gths \\
\hline 2055 & $29+11.2$ & litho cavy & & $\begin{array}{l}\text { anhedral cal - (bubbly opal) - blocky cal - msv silica - bladed cal - bubbly opal - bladed cal - bubbly opal - } \\
\text { cal o'gths }\end{array}$ \\
\hline 2056 & $29+22.9$ & fracture & calcite & anhedral cal - blocky cal -botry'l opal - bladed cal - scepter cal - bubbly opal \\
\hline 2057 & $29+62.2$ & fracture & calcite & $\begin{array}{l}\text { vapor phase - blocky cal - msv silica - bladed cal - opal coat - scepter o'gth - bubbly opal - cal o'gth - bubbly } \\
\text { opal }\end{array}$ \\
\hline 2058 & $29+79.98$ & fracture & calcite & vapor phase - blocky cal - msv silica - bladed cal - bubbly opal - scepter o'gth - (opal coat) \\
\hline 2059 & $30+17.78$ & litho cavy & silica, calcite & $\begin{array}{l}\text { vapor phase - msv silica - blocky cal - bladed cal - opal coat - scepter o'gth - bubbly opal - cal o'gth - bubbly } \\
\text { opal }\end{array}$ \\
\hline 2060 & $30+26.58$ & fracture? & calcite & vapor phase - (blocky cal) - bladed cal - scepter cal \\
\hline 2074 & $30+50.7$ & litho cavy & calcite & $\begin{array}{l}\text { vapor phase - blocky cal - msv silica- blocky cal - msv silica - bladed cal - bubbly opal - bladed cal - scepter } \\
\text { cal o'gth - bubbly opal - (cal o'gths) - (bubbly opal) }\end{array}$ \\
\hline 2061 & $30+57.68$ & litho cavy & (calcite) & vapor phase - msv silica - blocky cal - bladed cal - msv silica - blocky to bladed cal - bubbly opal - cal o'gths \\
\hline 2073 & $31+03$ & litho cavy & calcite & $\begin{array}{l}\text { vapor phase - bladed cal - zeolite + opal - bladed cal - scepter cal o'gth - bubbly opal - cal o'gth - bubbly } \\
\text { opal }\end{array}$ \\
\hline 2062 & $31+07.4$ & fracture & & blocky cal - bladed cal - opal coat - scepter cal o'gth - bubbly opal - cal o'gth - bubbly opal \\
\hline 2063 & $31+16.1$ & fracture & & blocky cal - bladed cal - scepter o'gths - bubbly opal \\
\hline 2064 & $31+95.7$ & litho cavy & & vapor phase - blocky cal - (msv silica) - bladed cal - opal coat - cal o'gth \\
\hline 2065 & $33+16.2$ & litho cavy & calcite & vapor phase - blocky cal - msv silica \pm ffourite - blocky cal - flourite - bladed cal - opal coat - cal o'gth \\
\hline 2066 & $33+95.78$ & litho cavy & calcite & vapor phase - msv silica - blocky cal - bladed cal - opal - cal o'gth - bubbly opal - cal o'gths \\
\hline 2067 & $34+28.18$ & fracture & & vapor phase - blocky cal - bladed cal \\
\hline 2068 & $34+86.48$ & litho cavy & (calcite) & vapor phase - msv silica - blocky cal - bladed cal - bubbly opal - cal o'gth - bubbly opal \\
\hline 2069 & $35+03.78$ & fracture & & blocky cal - botry'l opal - bladed cal - scepter cal o'gth \\
\hline 2070 & $35+23.63$ & fracture & calcite & (blocky cal) - short bladed cal - thin-bladed cal - scepter cal o'gth - opal coat \\
\hline 2071 & $35+45.4$ & fracture & calcite & fine grained blocky cal - coarser blocky cal - bladed cal - opal coat - cal o'gth \\
\hline 2072 & $35+57.2$ & fracture & & bladed cal \\
\hline 2090 & $36+54.9$ & fracture & calcite & blocky cal - coarser blocky cal \\
\hline 2076 & $36+97.5$ & litho cavy & & vapor phase - blocky cal - msv silica - (zeolite) - blocky cal - bladed cal \\
\hline 2080 & $37+60$ & fracture & & (blocky cal) - bladed cal - (scepter cal o'gth) \\
\hline $2077(A)$ & $37+62.9$ & fracture & & blocky cal - msv silica \pm fluorite - bladed cal - scepter cal o'gth \\
\hline
\end{tabular}


Appendix 1. Paragenetic sequences of secondary mineral occurrences within the Exploratory Studies Facility (ESF), Yucca Mountain, Nevada (Continued)

\begin{tabular}{|c|c|c|c|c|}
\hline Sample \# & ESF Location* & Type & $\begin{array}{c}\text { Basal } \\
\text { Dissolution }\end{array}$ & \\
\hline $2077(\mathrm{~B})$ & $37+62.9$ & fracture & & blocky cal - msv silica - bladed cal - scepter cal o'gth - bubbly opal - cal o'gth \\
\hline 2078 & $37+67$ & litho cavy & calcite & $\begin{array}{l}\text { vapor phase - blocky cal - msv silica - bladed cal - bubbly opal - scepter cal o'gth - opal coat + tiny bubbly } \\
\text { opal }\end{array}$ \\
\hline $2079(A)$ & $38+17.2$ & litho cavy & & msv silica - vapor phase - blocky cal \\
\hline 2079 (B) & $38+17.2$ & litho cavy & calcite & msv silica - vapor phase - blocky cal - bladed cal - scepter cal o'gth \\
\hline 2079 (C) & $38+17.2$ & litho cavy & calcite & $\begin{array}{l}\text { vapor phase - blocky cal w/ scattered msv silica - bladed cal - scepter cal o'gth - bubbly opal - cal o'gths - } \\
\text { opal coat - bubbly opal - cal o'gth }\end{array}$ \\
\hline 2081 & $38+61$ & litho cavy & & $\begin{array}{l}\text { vapor phase - blocky cal - coarser blocky cal + fluorite - bubbly opal - cal o'gth - coat to fine bubbly opal - } \\
\text { cal o'gth }\end{array}$ \\
\hline 2083 & $38+64.0$ & fracture & & blocky cal - bladed cal \\
\hline 2082 & $38+68.8$ & litho cavy & & vapor phase + msv silica - blocky cal - coarser blocky cal + fluorite - coat to bubbly opal - cal o'gth \\
\hline $2084(A)$ & $38+87.8$ & litho cavy & calcite & vapor phase - blocky cal - bladed cal - scepter cal o'gth - coat to bubbly opal - (cal o'gth) \\
\hline $2084(\mathrm{~B})$ & $38+87.8$ & fracture & & blocky to bladed cal - msv silica \\
\hline 2085 & $39+38.7$ & litho cavy & calcite & vapor phase + msv silica - flourite - blocky cal - bladed cal - scepter cal - bubbly opal - cal o'gth - (opal coat) \\
\hline 2086 & $39+44.0$ & $\begin{array}{l}\text { fracture } \\
\text { gouge }\end{array}$ & & multi-stage blocky cal \\
\hline 2087 & $39+50.7$ & litho cavy & & vapor phase - blocky cal - bladed cal - bubbly opal - bladed cal \pm cal o'gth - bubbly opal coat \\
\hline 2088 & $39+61$ & fracture & calcite & blocky cal - msv silica - blocky cal \\
\hline 2089 (A) & $39+91.4$ & litho cavy & calcite & vapor phase + msv silica - blocky cal - bladed cal - scepter cal o'gth - opal coat \\
\hline 2089 (B) & $39+91.4$ & litho cavy & calcite & vapor phase + msv silica - blocky cal - bladed cal - scepter cal o'gths - coat to bubbly opal - cal o'gth \\
\hline
\end{tabular}




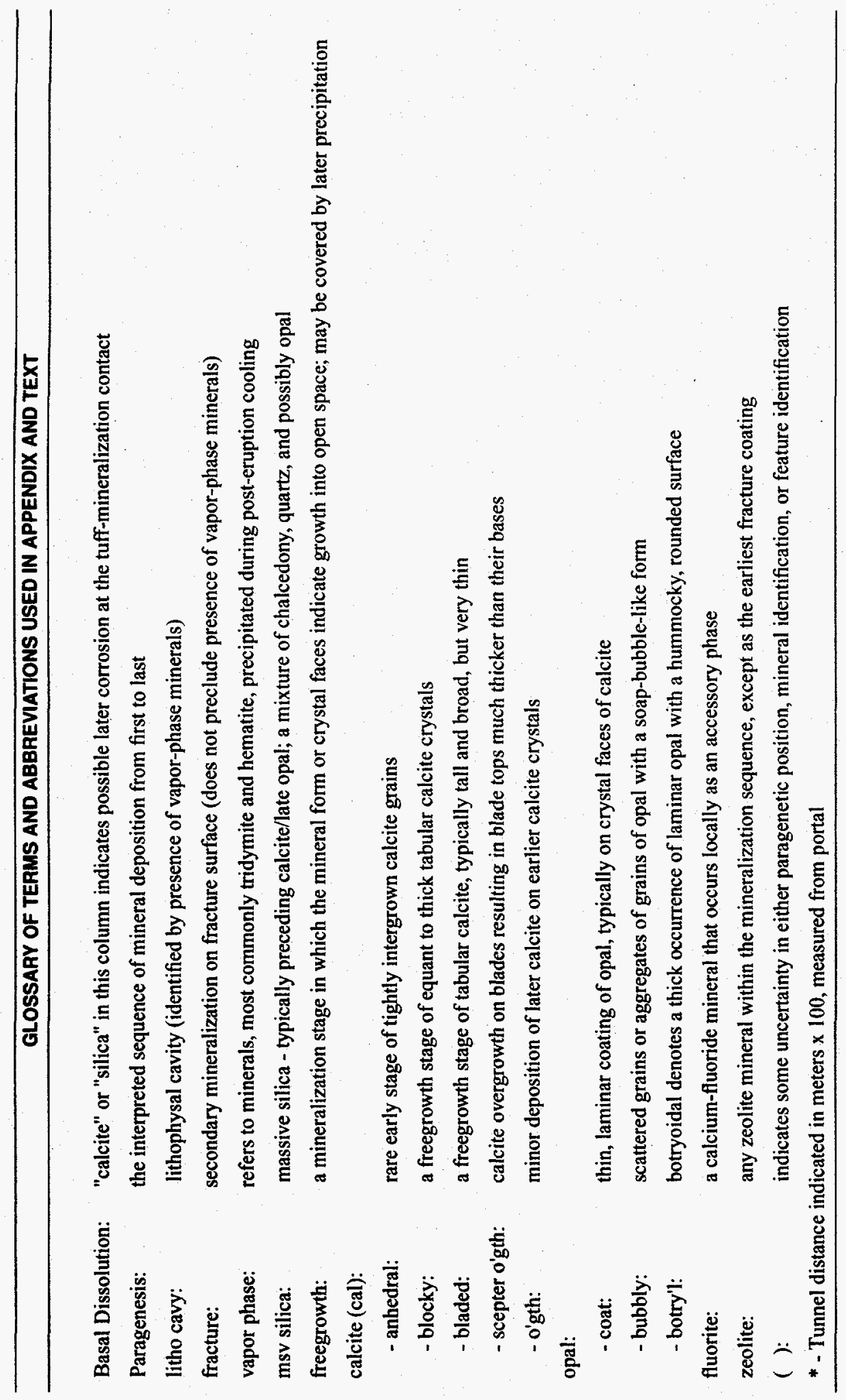


Appendix 2. Calcite delta carbon-13 and delta oxygen- 18 values from secondary mineral occurences within the Exploratory Studies Facility (ESF) and drill holes near Yucca Mountain, Nevada

\begin{tabular}{|c|c|c|c|c|}
\hline Sample \# & Locality & Depth/Distance: $\mathrm{m}^{*}$ & 813-C PDB & 818-0 SMOW \\
\hline HD-1837 b & ESF & 98.80 & -4.0 & 19.1 \\
\hline HD-1837d & ESF & 98.80 & -4.1 & 19.9 \\
\hline HD-1837c & ESF & 98.80 & -5.2 & 19.1 \\
\hline HD-1837d & ESF & 98.80 & -4.1 & 20.0 \\
\hline HD-1837 a & ESF & 98.90 & -3.4 & 19.7 \\
\hline HD-1836 Aa & ESF & 109.05 & -4.4 & 19.7 \\
\hline $\mathrm{HD}-1836 \mathrm{Ba}$ & ESF & 109.05 & -5.9 & 18.9 \\
\hline HD-1850 a & ESF & 111.17 & -5.7 & 19.1 \\
\hline $\mathrm{HD}-1850 \mathrm{~b}$ & ESF & 111.17 & -3.3 & 19.7 \\
\hline $\mathrm{HD}-1850 \mathrm{c}$ & ESF & 111.17 & -1.4 & 19.3 \\
\hline HD-1838 a & ESF & 111.55 & -6.7 & 19.0 \\
\hline HD-1838 b & ESF & 111.55 & -3.1 & 19.5 \\
\hline HD-1838 b & ESF & 111.55 & -3.2 & 19.6 \\
\hline HD-1852 a & ESF & 149.47 & -6.2 & 19.5 \\
\hline HD-1852 b & ESF & 149.47 & -3.0 & 17.6 \\
\hline HD-1852 a & ESF & 149.47 & -6.2 & 19.2 \\
\hline HD-1849 a & ESF & 161.90 & $-1,1$ & 12.8 \\
\hline HD-1919 sa & ESF & 168.20 & -4.5 & 18.4 \\
\hline HD-1927 sa & ESF & 168.20 & -6.1 & 19.4 \\
\hline HD-1933 sa & ESF & 168.20 & -5.0 & 18.4 \\
\hline HD-1933 sb & ESF & 168.20 & -6.3 & 19.5 \\
\hline HD-1839 a & ESF & 288.90 & -6.6 & 18.8 \\
\hline HD-1841 a & ESF & 301.80 & -2.6 & 20.6 \\
\hline HD-1840 a & ESF & 324.49 & -5.2 & 20.5 \\
\hline HD-1840 b & ESF & 324.49 & -5.3 & 20.1 \\
\hline HD-1948 sa & ESF & 336.79 & -5.5 & 19.4 \\
\hline HD- $1848 b$ & ESF & 358.95 & -5.2 & 20.2 \\
\hline HD-1844 a & ESF & 360.20 & -5.3 & 20.0 \\
\hline HD-1843 a & ESF & 371.00 & -5.5 & 19.6 \\
\hline $\mathrm{HD}-1847 \mathrm{a}$ & ESF & 375.19 & -5.5 & 19.9 \\
\hline HD-1847b & ESF & 375.19 & -5.2 & 20.5 \\
\hline HD-1875 a & ESF & 382.82 & -5.2 & 20.3 \\
\hline HD- 1880 a & ESF & 412.40 & -5.1 & 19.9 \\
\hline HD-1937 sa & ESF & 444.60 & -5.9 & 19.9 \\
\hline HD-1879 a & ESF & 454.04 & -5.3 & 20.5 \\
\hline HD-1881 a & ESF & 465.45 & -5.9 & 20.2 \\
\hline HD-1881 a & ESF & 465.45 & -6.0 & 20.1 \\
\hline HD-1877 b & ESF & 473.40 & -4.3 & 19.4 \\
\hline HD-1877a & ESF & 473.40 & 2.5 & 11.6 \\
\hline
\end{tabular}


Appendix 2. Calcite delta carbon-13 and delta oxygen-18 values from secondary mineral occurences within the Exploratory Studies Facility (ESF) and drill holes near Yucca Mountain, Nevada (Continued)

\begin{tabular}{|c|c|c|c|c|}
\hline Sample \# & Locality & Depth/Distance: $\mathbf{m}^{*}$ & 813-C PDB & 818-0 SMOW \\
\hline HD-1882 b & ESF & 473.40 & -5.6 & 19.9 \\
\hline HD-1883 b & ESF & 473.40 & -0.2 & 16.4 \\
\hline HD-1878 a & ESF & 483.05 & -6.1 & 20.0 \\
\hline HD- $1878 b$ & ESF & 483.05 & -5.4 & 19.9 \\
\hline HD-1940 sa & ESF & 509.09 & -5.7 & 20.0 \\
\hline HD-1940 sb & ESF & 509.09 & -5.9 & 20.2 \\
\hline HD-1945 sa & ESF & 513.20 & -4.8 & 19.7 \\
\hline HD-1945 sb & ESF & 513.20 & -5.0 & 20.1 \\
\hline HD-1873 a & ESF & 529.40 & -6.0 & 20.3 \\
\hline HD-1873 b & ESF & 529.40 & -5.8 & 20.1 \\
\hline HD-1941 sa & ESF & 529.40 & -2.1 & 20.3 \\
\hline HD-1865 a & ESF & 531.25 & -3.5 & 20.2 \\
\hline HD-1934 sa & ESF & 532.49 & -4.5 & 19.3 \\
\hline HD-1934 sb & ESF & 532.49 & -4.9 & 19.9 \\
\hline HD-1866 a & ESF & 556.95 & -6.5 & 19.9 \\
\hline HD-1944 sa & ESF & 556.95 & -6.2 & 19.0 \\
\hline HD-1869 a & ESF & 557.09 & -6.2 & 19.6 \\
\hline HD-1876 a & ESF & 577.03 & -6.4 & 19.4 \\
\hline HD-1868 a & ESF & 579.15 & -6.4 & 18.8 \\
\hline HD-1868 b & ESF & 579.15 & -6.2 & 19.4 \\
\hline HD-1867 a & ESF & 584.75 & -5.5 & 18.6 \\
\hline HD-1870 a & ESF & 588.15 & -5.5 & 18.2 \\
\hline HD- $1870 b$ & ESF & 588.15 & -6.6 & 19.0 \\
\hline HD-1872 a & ESF & 640.20 & -6.2 & 18.6 \\
\hline HD-1942 sa & ESF & 652.70 & -3.4 & 18.8 \\
\hline HD-1942 sb & ESF & 652.70 & -6.7 & 18.8 \\
\hline HD-1935 sa & ESF & 658.75 & -6.1 & 18.7 \\
\hline HD-1952 sa & ESF & 803.80 & -6.2 & 18.4 \\
\hline HD-1939 sa & ESF & 818.20 & -6.8 & 18.7 \\
\hline HD-1939 sa & ESF & 818.20 & -6.8 & 18.6 \\
\hline HD-1922 sb & ESF & 822.68 & -6.5 & 18.8 \\
\hline HD-1918 sa & ESF & 988.97 & -6.8 & 18.3 \\
\hline HD-1923 sa & ESF & 1008.00 & -9.0 & 18.6 \\
\hline HD-1932 sc & ESF & 1090.30 & -0.2 & 14.3 \\
\hline HD-1931 sa & ESF & 1114.75 & -4.6 & 18.1 \\
\hline HD-1929 sa & ESF & 1147.00 & -5.9 & 18.2 \\
\hline HD-1938 sa & ESF & 1212.05 & -0.2 & 18.2 \\
\hline $\mathrm{HD}-2021 \mathrm{sa}$ & ESF & 1221.83 & -6.2 & 17.7 \\
\hline HD-2023 sa & ESF & 1406.00 & -0.6 & 14.8 \\
\hline HD-2001 sa & ESF & 1420.00 & -2.5 & 17.3 \\
\hline
\end{tabular}

30 Applications of Isotope Geochemistry to the Reconstruction of Yucca Mountain, Nevada, Paleohydrology-Status of Investigations June 1996 
Appendix 2. Calcite delta carbon-13 and delta oxygen-18 values from secondary mineral occurences within the Exploratory Studies Facility (ESF) and drill holes near Yucca Mountain, Nevada (Continued)

\begin{tabular}{|c|c|c|c|c|}
\hline Sample \# & Locality & Depth/Distance: $\mathrm{m}^{\star}$ & 813-C PDB & 818-O SMOW \\
\hline HD-2001 sb & ESF & 1420.00 & 6.3 & 12.4 \\
\hline HD-2025 sa & ESF & 1455.00 & 6.9 & 13.0 \\
\hline $\mathrm{HD}-2025 \mathrm{sb}$ & ESF & 1455.00 & -3.7 & 18.2 \\
\hline HD-2026 sa & ESF & 1472.53 & -6.0 & 19.2 \\
\hline HD-2027 sa & ESF & 1479.55 & -2.0 & 18.1 \\
\hline HD-2028 sb & ESF & 1505.25 & -4.7 & 18.2 \\
\hline HD-2028 sa & ESF & 1505.25 & 2.9 & 14.4 \\
\hline HD-2029 sa & ESF & 1533.25 & 4.6 & 12.6 \\
\hline HD-2029 sb & ESF & 1533.25 & -4.6 & 18.3 \\
\hline HD-2030 sa & ESF & 1568.58 & 0.2 & 16.2 \\
\hline HD-2030 sb & ESF & 1568.58 & 3.6 & 15.1 \\
\hline HD-2002 sb & ESF & 1599.95 & 4.8 & 14.6 \\
\hline HD-2002 sc & ESF & 1599.95 & -5.7 & 17.7 \\
\hline HD-2002 sa & ESF & 1599.95 & 4.1 & 14.7 \\
\hline HD-2003 sa & ESF & 1612.38 & 6.2 & 11.5 \\
\hline HD-2003 sb & ESF & 1612.38 & 7.6 & 13.5 \\
\hline HD-2003 sc & ESF & 1612.38 & -6.2 & 17.5 \\
\hline HD-2004 sc & ESF & 1646.60 & 1.9 & 15.6 \\
\hline HD-2004 sb & ESF & 1646.60 & 8.4 & 13.0 \\
\hline HD-2004 sa & ESF & 1646.60 & 4.5 & 13.3 \\
\hline HD-2004 sb & ESF & 1646.60 & 8.3 & 12.9 \\
\hline HD-2032 sa & ESF & 1670.10 & 5.4 & 10.5 \\
\hline HD-2032 sb & ESF & 1670.10 & 5.8 & 12.3 \\
\hline HD-2032 sc & ESF & 1670.10 & 2.4 & 16.1 \\
\hline HD-2005 sa & ESF & 1710.95 & -6.3 & 17.8 \\
\hline HD-2005 sa & ESF & 1710.95 & -6.3 & 17.7 \\
\hline HD-2006 sa & ESF & 1900.00 & -0.6 & 15.0 \\
\hline HD-2006 sb & ESF & 1900.00 & 0.0 & 13.9 \\
\hline HD-2006 sc & ESF & 1900.00 & -6.2 & 17.7 \\
\hline HD-2075 sa & ESF & 1975.00 & -5.4 & 17.5 \\
\hline HD-2075 sb & ESF & 1975.00 & -4.6 & 13.6 \\
\hline HD-2075 sc & ESF & 1975.00 & -6.5 & 17.1 \\
\hline HD-2007 1sb & ESF & 2213.00 & -5.8 & 16.9 \\
\hline HD-2007 1sc & ESF & 2213.00 & -6.1 & 15.9 \\
\hline HD-2007 2sa & ESF & 2213.00 & -7.0 & 15.9 \\
\hline HD-2007 1sb & ESF & 2213.00 & -5.6 & 17.1 \\
\hline HD-2007 2sb & ESF & 2213.00 & -7.2 & 16.6 \\
\hline HD-2007 lsa & ESF & 2213.00 & -6.1 & 16.0 \\
\hline HD-2007 2sa & ESF & 2213.00 & -7.1 & 16.0 \\
\hline HD-2008 sa & ESF & 2272.00 & -4.2 & 17.2 \\
\hline
\end{tabular}


Appendix 2. Calcite delta carbon-13 and delta oxygen-18 values from secondary mineral occurences within the Exploratory Studies Facility (ESF) and drill holes near Yucca Mountain, Nevada (Continued)

\begin{tabular}{|c|c|c|c|c|}
\hline Sample \# & Locality & Depth/Distance: $\mathrm{m}^{*}$ & 813-C PDB & 818-0 SMOW \\
\hline HD-2008 sb & ESF & 2272.00 & -6.7 & 17.3 \\
\hline HD-2008 sa & ESF & 2272.00 & -4.7 & 15.4 \\
\hline HD-2020 subl sa & ESF & 2439.58 & -0.7 & 16.8 \\
\hline HD-2020 sub2 sb & ESF & 2439.58 & -1.9 & 16.3 \\
\hline HD-2020 sub2 sc & ESF & 2439.58 & -1.8 & 17.1 \\
\hline HD-2020 sub3 sd & ESF & 2439.58 & -2.7 & 16.5 \\
\hline HD-2020 sub1 sa & ESF & 2439.58 & -0.9 & 16.7 \\
\hline HD-2009 sa & ESF & 2443.50 & -3.8 & 17.0 \\
\hline HD-2009 sb & ESF & 2443.50 & -6.7 & 18.0 \\
\hline HD-2010 sa & ESF & 2468.20 & -6.9 & 18.0 \\
\hline HD-2010 sb & ESF & 2468.20 & -5.7 & 18.4 \\
\hline HD-2011 sa & ESF & 2568.00 & -1.2 & 16.7 \\
\hline HD-2011 sb & ESF & 2568.00 & -5.7 & 18.1 \\
\hline HD-2012 sa & ESF & 2576.70 & -4.1 & 17.4 \\
\hline HD-2012 sb & ESF & 2576.70 & -6.3 & 18.4 \\
\hline HD-2012 sc & ESF & 2576.70 & -5.8 & 17.4 \\
\hline HD-2013 sa & ESF & 2678.58 & 4.8 & 14.5 \\
\hline HD-2013 sb & ESF & 2678.58 & -4.1 & 16.7 \\
\hline HD-2014 sa & ESF & 2688.00 & -2.1 & 16.3 \\
\hline HD-2015 sb & ESF & 2695.00 & -5.7 & 16.8 \\
\hline HD-2016 sa & ESF & 2718.38 & -2.4 & 16.1 \\
\hline HD-2016 sb & ESF & 2718.38 & -2.3 & 15.9 \\
\hline HD-2016 sc & ESF & 2718.38 & -5.8 & 16.7 \\
\hline HD-2017 sa & ESF & 2724.00 & 4.2 & 14.1 \\
\hline HD-2017 sb & ESF & 2724.00 & -2.0 & 15.3 \\
\hline HD-2017 sc & ESF & 2724.00 & 0.6 & 15.8 \\
\hline HD-2017 sd & ESF & 2724.00 & -7.4 & 17.2 \\
\hline HD-2017 sb & ESF & 2724.00 & 0.7 & 15.6 \\
\hline HD-2018 sa & ESF & 2750.65 & 4.2 & 13.5 \\
\hline HD-2018 sb & ESF & 2750.65 & -7.3 & 16.9 \\
\hline HD-2019 sc & ESF & 2880.00 & 1.8 & 15.1 \\
\hline HD-2019 sd & ESF & 2880.00 & -2.6 & 13.8 \\
\hline HD-2019 sb & ESF & 2880.00 & 6.7 & 13.5 \\
\hline HD-2019 se & ESF & 2880.00 & -3.4 & 15.3 \\
\hline HD-2019 sf & ESF & 2880.00 & -7.2 & 17.2 \\
\hline HD-2019 sa & ESF & 2881.00 & -5.3 & 16.6 \\
\hline HD-2019 sg & ESF & 2881.00 & 4.9 & 13.2 \\
\hline HD-2019 sh & ESF & 2881.00 & -6.9 & 16.6 \\
\hline HD-2054 sc & ESF & 2881.60 & 4.2 & 14.7 \\
\hline HD-2054 sd & ESF & 2881.60 & 1.6 & 15.2 \\
\hline
\end{tabular}

32 Applications of Isotope Geochemistry to the Reconstruction of Yucca Mountain, Nevada, Paleohydrology-Status of Investigations June 1996 
Appendix 2. Calcite delta carbon-13 and delta oxygen-18 values from secondary mineral occurences within the Exploratory Studies Facility (ESF) and drill holes near Yucca Mountain, Nevada (Continued)

\begin{tabular}{|c|c|c|c|c|}
\hline Sample \# & Locality & Depth/Distance: $m^{*}$ & $813-\mathrm{C} \mathrm{PDB}$ & $\delta 18-0$ SMOW \\
\hline HD-2054 se & ESF & 2881.60 & -6.9 & 16.7 \\
\hline HD-2054 sa & ESF & 2881.60 & 4.9 & 14.2 \\
\hline HD-2054 sb & ESF & 2881.60 & 4.2 & 13.7 \\
\hline HD-2055 sb & ESF & 2911.20 & -2.0 & 15.7 \\
\hline HD-2055 sc & ESF & 2911.20 & -5.6 & 16.9 \\
\hline HD-2055 se & ESF & 2911.20 & -6.7 & 17.8 \\
\hline HD-2055 sa & ESF & 2911.20 & 7.7 & 14.0 \\
\hline HD-2055 sd & ESF & 2911.20 & -6.9 & 17.6 \\
\hline HD-2056 sa & ESF & 2922.90 & -6.2 & 17.0 \\
\hline HD-2056 sc & ESF & 2922.90 & -1.5 & 16.4 \\
\hline HD-2056 sb & ESF & 2922.90 & -3.1 & 16.8 \\
\hline $\mathrm{HD}-2056 \mathrm{sd}$ & ESF & 2922.90 & -2.5 & 16.4 \\
\hline HD-2056 se & ESF & 2922.90 & -6.8 & 17.4 \\
\hline HD-2057 sa & ESF & 2962.20 & -7.3 & 17.3 \\
\hline HD-2057 sa & ESF & 2962.20 & -7.3 & 17.3 \\
\hline HD-2057 sa & ESF & 2962.20 & -7.4 & 17.4 \\
\hline HD-2057 sc & ESF & 2962.20 & 5.0 & 15.6 \\
\hline HD-2057 se & ESF & 2962.20 & -7.3 & 17.5 \\
\hline HD-2057 sb & ESF & 2962.20 & 6.8 & 14.0 \\
\hline HD-2057 sg & ESF & 2962.20 & 0.4 & 16.7 \\
\hline HD-2057 sd & ESF & 2962.20 & 0.8 & 17.4 \\
\hline HD-2057 sf & ESF & 2962.20 & -7.8 & 17.2 \\
\hline HD-2058 sc & ESF & 2979.98 & -6.8 & 17.5 \\
\hline HD-2058 sa & ESF & 2979.98 & 0.4 & 16.5 \\
\hline HD-2058 sb & ESF & 2979.98 & -0.4 & 16.9 \\
\hline HD-2058 sd & ESF & 2979.98 & -7.7 & 16.8 \\
\hline HD-2059 sc & ESF & 3017.78 & -7.2 & 16.7 \\
\hline HD-2059 se & ESF & 3017.78 & -7.3 & 16.8 \\
\hline HD-2059 sa & ESF & 3017.78 & -8.0 & 16.9 \\
\hline HD-2059 sb & ESF & 3017.78 & -8.1 & 16.7 \\
\hline HD-2059 sf & ESF & 3017.78 & 3.5 & 14.9 \\
\hline HD-2059 sk & ESF & 3017.78 & -6.0 & 16.6 \\
\hline HD-2059 sl & ESF & 3017.78 & -7.2 & 16.9 \\
\hline HD-2059 sj & ESF & 3017.78 & -0.6 & 15.8 \\
\hline HD-2059 si & ESF & 3017.78 & 1.7 & 15.1 \\
\hline HD-2059 sj & ESF & 3017.78 & -0.5 & 15.6 \\
\hline HD-2059 sl & ESF & 3017.78 & -7.2 & 16.8 \\
\hline HD-2060 sb & ESF & 3026.58 & -5.1 & 16.3 \\
\hline HD-2060 sc & ESF & 3026.58 & -7.1 & 16.8 \\
\hline HD-2060 sa & ESF & 3026.58 & 4.4 & 14.1 \\
\hline
\end{tabular}


Appendix 2. Calcite delta carbon-13 and delta oxygen-18 values from secondary mineral occurences within the Exploratory Studies Facility (ESF) and drill holes near Yucca Mountain, Nevada (Continued)

\begin{tabular}{|c|c|c|c|c|}
\hline Sample \# & Locality & Depth/Distance: $\mathrm{m}^{*}$ & 813-C PDB & $\delta 18-0$ SMOW \\
\hline HD-2074 sb & ESF & 3050.70 & 5.9 & 14.6 \\
\hline HD-2074 sc & ESF & 3050.70 & 0.8 & 14.6 \\
\hline HD-2074 sd & ESF & 3050.70 & -3.2 & 14.5 \\
\hline HD-2074 se & ESF & 3050.70 & -7.3 & 17.0 \\
\hline HD-2061 sc & ESF & 3057.68 & 6.5 & 14.6 \\
\hline HD-2061 sd & ESF & 3057.68 & -3.1 & 15.7 \\
\hline HD-2061 se & ESF & 3057.68 & -1.2 & 14.8 \\
\hline HD-2061 sf & ESF & 3057.68 & -6.4 & 16.9 \\
\hline HD-2061 sg & ESF & 3057.68 & -7.2 & 16.9 \\
\hline HD-2061 sb & ESF & 3057.68 & 2.0 & 14.9 \\
\hline HD-2061 sb & ESF & 3057.68 & 2.5 & 14.8 \\
\hline HD-2073 sb & ESF & 3103.00 & -2.2 & 14.8 \\
\hline HD-2073 sc & ESF & 3103.00 & -6.6 & 17.5 \\
\hline HD-2073 sd & ESF & 3103.00 & -7.5 & 17.3 \\
\hline HD-2073 se & ESF & 3103.00 & -7.5 & 16.9 \\
\hline HD-2073 sa & ESF & 3103.00 & 6.2 & 14.6 \\
\hline HD-2073 se & ESF & 3103.00 & -7.6 & 16.9 \\
\hline HD-2073 sc & ESF & 3103.00 & -6.8 & 17.1 \\
\hline HD-2062 sa & ESF & 3107.40 & -7.1 & 17.5 \\
\hline HD-2062 sb & ESF & 3107.40 & -0.3 & 16.1 \\
\hline HD-2062 sc & ESF & 3107.40 & -6.8 & 17.3 \\
\hline HD-2062 sd & ESF & 3107.40 & -7.6 & 17.2 \\
\hline HD-2063 sa & ESF & 3116.10 & 0.0 & 16.7 \\
\hline HD-2063 sb & ESF & 3116.10 & -5.8 & 17.2 \\
\hline HD-2064 sa & ESF & 3195.70 & 1.9 & 15.5 \\
\hline HD-2065 sa & ESF & 3316.20 & 7.4 & 15.0 \\
\hline HD-2065 sb & ESF & 3316.20 & 4.9 & 15.2 \\
\hline HD-2065 sc & ESF & 3316.20 & 6.3 & 14.7 \\
\hline HD-2065 sd & ESF & 3316.20 & 6.7 & 14.5 \\
\hline HD-2065 sf & ESF & 3316.20 & 7.4 & 14.7 \\
\hline HD-2065 sg & ESF & 3316.20 & 7.2 & 14.7 \\
\hline HD-2065 sh & ESF & 3316.20 & 6.3 & 14.8 \\
\hline HD-2065 si & ESF & 3316.20 & 5.0 & 15.4 \\
\hline HD-2065 sj & ESF & 3316.20 & 6.8 & 14.6 \\
\hline HD-2065 sk & ESF & 3316.20 & 6.6 & 14.3 \\
\hline HD-2065 sl & ESF & 3316.20 & 4.1 & 15.2 \\
\hline HD-2065 sn & ESF & 3316.20 & -6.5 & 17.5 \\
\hline HD-2065 sc & ESF & 3316.20 & 6.4 & 14.5 \\
\hline HD-2065 se & ESF & 3316.20 & 6.8 & 14.4 \\
\hline HD-2066 sa & ESF & 3395.78 & -1.6 & 17.4 \\
\hline
\end{tabular}


Appendix 2. Calcite delta carbon-13 and delta oxygen-18 values from secondary mineral occurences within the Exploratory Studies Facility (ESF) and drill holes near Yucca Mountain, Nevada (Continued)

\begin{tabular}{|c|c|c|c|c|}
\hline Sample \# & Locality & Depth/Distance: $m^{*}$ & 813-C PDB & $\delta 18-0$ SMOW \\
\hline HD-2066 sb & ESF & 3395.78 & -2.1 & 17.5 \\
\hline HD-2066 sc & ESF & $3395: 78$ & -5.7 & 18.3 \\
\hline HD-2066 sd & ESF & 3395.78 & -7.0 & 17.7 \\
\hline HD-2066 se & ESF & 3395.78 & -6.4 & 18.5 \\
\hline HD-2067 sb & ESF & 3428.18 & -0.9 & 16.5 \\
\hline HD-2067 sc & ESF & 3428.18 & -5.3 & 17.1 \\
\hline HD-2067 sd & ESF & 3428.18 & 1.0 & 15.9 \\
\hline HD-2067 sa & ESF & 3428.18 & -0.6 & 16.9 \\
\hline HD-2068 sa & ESF & 3486.48 & 0.1 & 16.0 \\
\hline HD-2068 sb & ESF & 3486.48 & -5.8 & 17.3 \\
\hline HD-2069 sb & ESF & 3503.78 & -3.3 & 16.1 \\
\hline HD-2069 sc & ESF & 3503.78 & -6.5 & 16.9 \\
\hline HD-2069 sc & ESF & 3503.78 & -6.4 & 17.1 \\
\hline HD-2069 sa & ESF & 3503.78 & 2.3 & 15.3 \\
\hline HD-2070 sa & ESF & 3523.63 & -1.5 & 15.8 \\
\hline HD-2070 sb & ESF & 3523.63 & -6.4 & 17.1 \\
\hline HD-2071 sa & ESF & 3545.40 & 1.5 & 15.1 \\
\hline HD-2071 sb & ESF & 3545.40 & 5.3 & 14.8 \\
\hline HD-2071 sc & ESF & 3545.40 & -6.4 & 17.2 \\
\hline HD-2071 sd & ESF & 3545.40 & -5.5 & 17.3 \\
\hline HD-2071 se & ESF & 3545.40 & 2.0 & 15.0 \\
\hline HD-2072 sa & ESF & 3557.20 & 3.4 & 14.7 \\
\hline HD-2076 sa & ESF & 3697.50 & -1.4 & 15.7 \\
\hline HD-2076 sb & ESF & 3697.50 & -2.5 & 15.5 \\
\hline HD-2076 sc & ESF & 3697.50 & -6.1 & 16.5 \\
\hline HD-2077 Asa & ESF & 3762.90 & 1.8 & 15.4 \\
\hline HD-2077 Asb & ESF & 3762.90 & -6.4 & 17.6 \\
\hline HD-2077 Bsc & ESF & 3762.90 & 4.3 & 14.5 \\
\hline HD-2077 Bsd & ESF & 3762.90 & -1.5 & 15.9 \\
\hline HD-2077 Bse & ESF & 3762.90 & -7.7 & 17.5 \\
\hline HD-2078 sb & ESF & 3767.00 & -0.6 & 15.6 \\
\hline HD-2078 sc & ESF & 3767.00 & -0.8 & 15.5 \\
\hline HD-2078 sd & ESF & 3767.00 & -6.5 & 17.6 \\
\hline HD-2078 sa & ESF & 3767.00 & 2.4 & 15.6 \\
\hline HD-2079 Asa & ESF & 3817.20 & -1.2 & 16.4 \\
\hline HD-2079 Bsb & ESF & 3817.20 & 3.2 & 15.7 \\
\hline HD-2079 Bsc & ESF & 3817.20 & -3.3 & 17.0 \\
\hline HD-2079 Bsd & ESF & 3817.20 & -6.0 & 17.6 \\
\hline HD-2079 Cse & ESF & 3817.20 & 1.5 & 16.2 \\
\hline HD-2079 Csf & ESF & 3817.20 & -0.1 & 16.4 \\
\hline
\end{tabular}


Appendix 2. Calcite delta carbon-13 and delta oxygen-18 values from secondary mineral occurences within the Exploratory Studies Facility (ESF) and drill holes near Yucca Mountain, Nevada (Continued)

\begin{tabular}{|c|c|c|c|c|}
\hline Sample \# & Locality & Depth/Distance: $\mathrm{m}^{\star}$ & 813-C PDB & \$18-O SMOW \\
\hline HD-2079 Csg & ESF & 3817.20 & -7.0 & 18.0 \\
\hline HD-2079 Csh & ESF & 3817.20 & -7.2 & 18.0 \\
\hline HD-2081 sc & ESF & 3861.00 & -7.0 & 17.5 \\
\hline HD-2081 sa & ESF & 3861.00 & 2.8 & 16.4 \\
\hline HD-2081 sb & ESF & 3861.00 & -0.5 & 16.9 \\
\hline HD-2083 sa & ESF & 3864.00 & -0.6 & 16.5 \\
\hline HD-2083 sb & ESF & 3864.00 & 2.8 & 15.7 \\
\hline HD-2083 sc & ESF & 3864.00 & 3.6 & 15.3 \\
\hline HD-2083 sd & ESF & 3864.00 & -5.4 & 16.9 \\
\hline HD-2082 sb & ESF & 3868.80 & 2.0 & 15.3 \\
\hline HD-2084 Asa & ESF & $3887.80^{\circ}$ & 0.3 & 15.5 \\
\hline HD-2084 Asb & ESF & 3887.80 & -7.0 & 17.0 \\
\hline HD-2084 Asb & ESF & 3887.80 & -7.1 & 17.0 \\
\hline HD-2084 Bsa & ESF & 3887.80 & 1.8 & 15.9 \\
\hline HD-2084 Bsb & ESF & 3887.80 & -3.3 & 17.6 \\
\hline HD-2085 sa & ESF & 3938.70 & 1.2 & 15.7 \\
\hline $\mathrm{HD}-2085 \mathrm{sb}$ & ESF & 3938.70 & 0.9 & 15.7 \\
\hline $\mathrm{HD}-2086 \mathrm{sa}$ & ESF & 3944.00 & 5.1 & 14.7 \\
\hline HD-2086 sb & ESF & 3944.00 & -3.1 & 17.2 \\
\hline $\mathrm{HD}-2086 \mathrm{sc}$ & ESF & 3944.00 & -5.8 & 17.5 \\
\hline HD-2086 sc & ESF & 3944.00 & -6.0 & 17.4 \\
\hline HD-2087 sb & ESF & 3950.70 & -5.8 & 17.5 \\
\hline HD-2087 sa & ESF & 3950.70 & -2.4 & 16.9 \\
\hline HD-2088 sa & ESF & 3961.00 & 4.4 & 14.6 \\
\hline HD-2088 sb & ESF & 3961.00 & 3.4 & 14.9 \\
\hline HD-2088 sc & ESF & 3961.00 & 4.7 & 14.5 \\
\hline HD-2089 Asa & ESF & 3991.40 & -0.1 & 15.7 \\
\hline HD-2089 Asa & ESF & 3991.40 & -0.5 & 15.9 \\
\hline HD-2089 Asb & ESF & 3991.40 & -5.5 & 17.3 \\
\hline HD-2089 Bsa & ESF & 3991.40 & -3.5 & 16.5 \\
\hline HD-2089 Bsb & ESF & 3991.40 & -5.8 & 17.3 \\
\hline HD-769 a & UE-25 A-7 & 47.70 & -7.0 & 18.6 \\
\hline HD-776 a & UE-25 A-7 & 92.90 & -5.1 & 17.7 \\
\hline HD-777 a & UE-25 A-7 & 94.80 & 6.2 & 14.8 \\
\hline HD-778 a & UE-25 A-7 & 95.80 & -6.1 & 17.7 \\
\hline HD-779 a & UE-25 A-7 & 97.80 & -6.7 & 17.8 \\
\hline HD-780 a & UE-25 A-7 & 102.90 & -6.2 & 17.8 \\
\hline HD-780 c & UE-25 A-7 & 102.90 & -5.6 & 16.9 \\
\hline HD-780 b & UE-25 A-7 & 102.90 & -5.2 & 16.0 \\
\hline HD-781 a & UE-25 A-7 & 105.90 & -4.1 & 16.5 \\
\hline
\end{tabular}

36 Applications of Isotope Geochemistry to the Reconstruction of Yucca Mountain, Nevada, Paleohydrology-Status of Investigations June 1996 
Appendix 2. Calcite delta carbon-13 and delta oxygen-18 values from secondary mineral occurences within the Exploratory Studies Facility (ESF) and drill holes near Yucca Mountain, Nevada (Continued)

\begin{tabular}{|c|c|c|c|c|}
\hline Sample \# & Locality & Depth/Distance: $\mathbf{m}^{*}$ & $\delta 13-\mathrm{C} \mathrm{PDB}$ & 818-0 SMOW \\
\hline HD-781 a & UE-25 A-7 & 105.90 & -4.1 & 16.6 \\
\hline HD-783 a & UE-25 A-7 & 108.10 & -6.5 & 17.8 \\
\hline HD-784 c & UE-25 A-7 & 113.00 & -4.5 & 16.8 \\
\hline HD-785 a & UE- 25 A-7 & 117.30 & -4.5 & 17.8 \\
\hline HD-786 a & UE-25 A-7 & 124.40 & -6.4 & 17.6 \\
\hline HD-787 a & UE-25 A-7 & 128.80 & -6.9 & 17.8 \\
\hline HD-788 a & UE-25 A-7 & 131.00 & -5.5 & 17.9 \\
\hline HD-790 a & UE-25 A-7 & 140.60 & -5.5 & 14.8 \\
\hline HD-790 a & UE-25 A-7 & 140.60 & -5.5 & 14.8 \\
\hline HD-791 a & UE-25 A-7 & 143.50 & -6.3 & 17.9 \\
\hline HD-791 b & UE-25 A-7 & 143.50 & 1.0 & 14.0 \\
\hline HD-1833 a & UE-25 UZ-14 & 94.10 & -4.8 & 15.2 \\
\hline HD-1834 a & UE-25 UZ-14 & 179.20 & -6.0 & 16.2 \\
\hline HD- 1835 a & UE-25 UZ-14 & 246.90 & 6.2 & 13.2 \\
\hline HD-1835 a & UE-25 UZ-14 & 246.90 & 6.8 & 13.0 \\
\hline HD-1644 a & USW SD-12 & 2.40 & -7.1 & 20.0 \\
\hline HD-1650 a & USW SD-12 & 22.10 & -6.0 & 19.7 \\
\hline HD-1651 a & USW SD-12 & 25.80 & -6.2 & 19.8 \\
\hline HD-1652 a & USW SD-12 & 26.50 & -5.1 & 19.5 \\
\hline HD-1653 a & USW SD-12 & 28.10 & -6.1 & 19.8 \\
\hline HD-1654 b & USW SD-12 & 30.20 & -4.3 & 19.4 \\
\hline HD-1654 a & USW SD-12 & 30.20 & -3.6 & 19.3 \\
\hline HD-1655 a & USW SD-12 & 32.90 & -7.3 & 20.0 \\
\hline HD-1655 b & USW SD-12 & 32.90 & -4.5 & 19.6 \\
\hline HD-1655c & USW SD-12 & 32.90 & -6.4 & 19.3 \\
\hline HD-1655 a & USW SD-12 & 32.90 & -7.3 & 19.9 \\
\hline HD-1656 a & USW SD-12 & 37.90 & -5.4 & 20.0 \\
\hline HD-1656 b & USW SD-12 & 37.90 & -6.3 & 19.1 \\
\hline HD-1657 a & USW SD-12 & 42.40 & -5.8 & 19.1 \\
\hline HD-1658 a & USW SD-12 & 46.60 & -8.0 & 19.0 \\
\hline HD-1659 a & USW SD-12 & 48.20 & -7.4 & 19.4 \\
\hline$H D-1660 a$ & USW SD-12 & 48.70 & -5.6 & 19.0 \\
\hline HD-1661 a & USW SD-12 & 51.40 & -5.0 & 19.9 \\
\hline HD-1662 a & USW SD-12 & 54.20 & -5.4 & 19.5 \\
\hline HD-1663 a & USW SD-12 & 57.10 & -2.4 & 18.7 \\
\hline HD-1664 a & USW SD-12 & 63.70 & -3.9 & 19.1 \\
\hline HD-1665 a & USW SD-12 & 75.40 & -7.3 & 18.9 \\
\hline HD-1666 a & USW SD-12 & 77.20 & -7.0 & 19.3 \\
\hline HD-1667 a & USW SD-12 & 100.90 & -5.2 & 18.7 \\
\hline $\mathrm{HD}-1667 \mathrm{~b}$ & USW SD-12 & 100.90 & -5.3 & 18.6 \\
\hline
\end{tabular}


Appendix 2. Calcite delta carbon-13 and delta oxygen-18 values from secondary mineral occurences within the Exploratory Studies Facility (ESF) and drill holes near Yucca Mountain, Nevada (Continued)

\begin{tabular}{|c|c|c|c|c|}
\hline Sample \# & Locality & Depth/Distance: $\mathrm{m}^{\star}$ & 813-C PDB & 818-O SMOW \\
\hline HD-1668 a & USW SD-12 & 132.60 & -3.9 & 18.3 \\
\hline HD-1669 a & USW SD-12 & 141.80 & -5.2 & 18.5 \\
\hline HD-1669 a & USW SD-12 & 141.80 & -5.2 & 18.5 \\
\hline HD-1670a & USW SD-12 & 146.70 & -4.5 & 18.3 \\
\hline HD-1671 a & USW SD- 12 & 149.30 & -6.3 & 18.8 \\
\hline HD-1672 a & USW SD-12 & 160.60 & -3.6 & 17.8 \\
\hline HD-1675 a & USW SD- 12 & 223.30 & -4.5 & 17.3 \\
\hline HD-1675 a & USW SD-12 & 223.30 & -4.2 & 17.2 \\
\hline HD-1676 a & USW SD-12 & 223.50 & -1.7 & 16.6 \\
\hline HD-1677 a & USW SD-12 & 282.50 & -0.5 & 15.9 \\
\hline HD-1677 b & USW SD-12 & 282.50 & -1.4 & 16.1 \\
\hline HD-1887 a & USW SD-7 & 17.40 & -6.9 & 20.6 \\
\hline HD-1887 b & USW SD-7 & 17.40 & -6.8 & 20.6 \\
\hline HD-1888 a & USW SD-7 & 34.00 & -7.5 & 19.5 \\
\hline HD-1890 a & USW SD-7 & 49.80 & -7.3 & 20.2 \\
\hline HD-1891 a & USW SD-7 & 94.40 & -7.3 & 19.1 \\
\hline HD-1892 a & USW SD-7 & 95.20 & -7.3 & 19.7 \\
\hline HD-1896 b & USW SD-7 & 301.90 & -6.7 & 17.6 \\
\hline HD-747 b & USW VH-1 & 563.80 & -0.5 & 25.5 \\
\hline HD- $1250 \mathrm{a}$ & USW VH-2 & 301.90 & -1.2 & 17.9 \\
\hline HD-1250 a & USW VH-2 & 301.90 & -1.2 & 18.2 \\
\hline HD- $1251 \mathrm{a}$ & USW VH-2 & 346.80 & -1.1 & 16.3 \\
\hline HD- $1251 b$ & USW VH-2 & 346.80 & -1.6 & 16.0 \\
\hline HD-1252 a & USW VH-2 & 349.20 & 0.4 & 15.2 \\
\hline $\mathrm{HD}-1252 \mathrm{~b}$ & USW VH-2 & 349.20 & -1.0 & 16.0 \\
\hline HD-728 b & USW VH-2 & 354.10 & -0.7 & 17.0 \\
\hline $\mathrm{HD}-728$ a & USW VH-2 & 354.10 & 1.0 & 13.8 \\
\hline HD-729 b & USW VH-2 & 356.30 & -1.3 & 25.1 \\
\hline HD-730 a & USW VH-2 & 364.40 & -2.9 & 14.8 \\
\hline HD-730 b & USW VH-2 & 364.40 & -0.7 & 15.3 \\
\hline HD-731 c & USW VH-2 & 370.40 & -1.5 & 15.3 \\
\hline HD-731 a & USW VH-2 & 370.40 & -4.3 & 16.3 \\
\hline HD-731 b & USW VH-2 & 370.40 & -4.3 & 17.0 \\
\hline HD-732 b & USW VH-2 & 372.30 & -4.5 & 16.9 \\
\hline HD-732 d & USW VH-2 & 372.30 & -2.1 & 14.5 \\
\hline HD-732 c & USW VH-2 & 372.30 & -0.6 & 15.7 \\
\hline HD-732 a & USW VH-2 & 372.30 & -8.0 & 16.6 \\
\hline HD-733 a & USW VH-2 & 375.80 & -0.6 & 15.1 \\
\hline HD-733 a & USW VH-2 & 375.80 & -0.5 & 15.1 \\
\hline HD-734 b & USW VH-2 & 379.00 & -1.8 & 14.8 \\
\hline
\end{tabular}

38 Applications of Isotope Geochemistry to the Reconstruction of Yucca Mountain, Nevada, Paleohydrology-Status of Investigations June 1996 
Appendix 2. Calcite delta carbon-13 and delta oxygen- 18 values from secondary mineral occurences within the Exploratory Studies Facility (ESF) and drill holes near Yucca Mountain, Nevada (Continued)

\begin{tabular}{|c|c|c|c|c|}
\hline Sample \# & Locality & Depth/Distance: $m^{*}$ & 813-C PDB & 818-0 SMOW \\
\hline HD-734 c & USW VH-2 & 379.00 & -1.9 & 14.5 \\
\hline HD-734 a & USW VH-2 & 379.00 & -3.9 & 16.4 \\
\hline HD-735 a & USW VH-2 & 385.80 & -0.8 & 14.9 \\
\hline HD-736 a & USW VH-2 & 388.90 & -4.0 & 16.4 \\
\hline HD-736 b & USW VH-2 & 388.90 & -0.9 & 15.0 \\
\hline HD-742 a & USW VH-2 & 490.60 & -4.1 & 14.8 \\
\hline HD-742 b & USW VH-2 & 490.60 & -2.0 & 13.5 \\
\hline HD-743 b & USW VH-2 & 535.10 & 0.8 & 25.7 \\
\hline HD-743 a & USW VH-2 & 535.10 & -0.2 & 23.6 \\
\hline HD-743 c & USW VH-2 & 535.10 & 0.4 & 24.8 \\
\hline HD-744 b & USW VH-2 & 538.30 & 0.3 & 20.4 \\
\hline HD-745 b & USW VH-2 & 550.50 & -0.1 & 26.8 \\
\hline HD-745 a & USW VH-2 & 550.50 & 0.1 & 24.2 \\
\hline $\mathrm{HD}-747 \mathrm{a}$ & USW VH-2 & 563.80 & 0.0 & 14.2 \\
\hline HD-748 b & USW VH-2 & 571.40 & 2.5 & 12.9 \\
\hline HD-748 a & USW VH-2 & 571.40 & 3.1 & 12.8 \\
\hline HD-748 c & USW VH-2 & 571.40 & 1.3 & 19.2 \\
\hline HD-749 b & USW VH-2 & 581.00 & 2.8 & 12.5 \\
\hline HD-749a & USW VH-2 & 581.00 & 2.6 & 12.9 \\
\hline HD-749 c & USW VH-2 & 581.00 & 0.9 & 18.8 \\
\hline HD-749 c & USW VH-2 & 581.00 & 0.9 & 18.7 \\
\hline $\mathrm{HD}-750 \mathrm{~b}$ & USW VH-2 & 595.20 & 0.9 & 12.7 \\
\hline $\mathrm{HD}-750 \mathrm{a}$ & USW VH-2 & 595.20 & 1.4 & 15.5 \\
\hline HD-750 d & USW VH-2 & 595.20 & 0.0 & 20.5 \\
\hline HD-759 a & USW VH-2 & 854.30 & 1.5 & 4.4 \\
\hline HD-759 b & USW VH-2 & 854.30 & -1.9 & 13.0 \\
\hline HD-760 a & USW VH-2 & 865.30 & 1.4 & 5.7 \\
\hline $\mathrm{HD}-760 \mathrm{~b}$ & USW VH-2 & 865.30 & -0.6 & 9.5 \\
\hline HD-761 b & USW VH-2 & 871.50 & 0.9 & 7.2 \\
\hline HD-761 a & USW VH-2 & 871.50 & -1.9 & 11.6 \\
\hline HD-761 b & USW VH-2 & 871.50 & 0.9 & 7.2 \\
\hline HD-763 a & USW VH-2 & 874.60 & -2.2 & 13.0 \\
\hline HD-763 b & USW VH-2 & 874.60 & 0.3 & 7.6 \\
\hline HD-764 a & USW VH-2 & 897.50 & 0.5 & 8.3 \\
\hline \multicolumn{5}{|c|}{ *-Depth in borehole or distance from ESF portal (in meters) } \\
\hline \multicolumn{5}{|c|}{ PDB-Pee Dee Belemnite standard } \\
\hline \multicolumn{5}{|c|}{ SMOW-Standard Mean Ocean Water standard } \\
\hline
\end{tabular}


Appendix 3. Secondary silica and calcite delta oxygen-18 values from the Exploratory Studies Facility (ESF), drill holes, and outcrop samples obtained near Yucca Mountain, Nevada, and from the Bullfrog Mine.

\begin{tabular}{|c|c|c|c|c|c|c|}
\hline Sample & Lab & Locality & Depth (tt) & Tuff Member & $\begin{array}{c}\text { 818-O SMOW } \\
\text { for sillica }\end{array}$ & $\begin{array}{l}\delta 18-0 \text { SMOW } \\
\text { for calcite }\end{array}$ \\
\hline HD-306c opal & ASU & UE-25 a\#1 & 253 & Tiva Canyon & 18.6 & 16.9 \\
\hline HD-35lb opal & ASU & USW G-2 & 92.2 & Tiva Canyon & 26.6 & 20.7 \\
\hline HD-355a opal & $\mathrm{ASU}$ & USW G-2 & 236.7 & Tiva Canyon & 20.5 & 17.9 \\
\hline HD-356a opal & ASU & USW G-2 & 240.7 & Tiva Canyon & 21.7 & 19.0 \\
\hline HD-358a opal & ASU & USW G-2 & 257.8 & Yucca Mtn & 24.1 & 17.4 \\
\hline HD-362a opal & ASU & USW G-2 & 280.2 & Yucca Mtn & 21.2 & 18.7 \\
\hline HD-929a opal & ASU & UE-25 a\#5 & 92.2 & Tiva Canyon & 23.3 & 17.9 \\
\hline HD-926a opal & ASU & UE-25 a\#5 & 85.2 & Tiva Canyon & 21.9 & 17.7 \\
\hline HD-700a opal & ASU & USW G-4 & 74.2 & Tiva Canyon & 24.1 & no cal \\
\hline 349,P2 Cut 1 & ASU & Trench 14 & & pedogenic & 22.6 & 20.0 \\
\hline 349, P2 Cut $2^{*}$ & $\mathrm{ASU}$ & Trench 14 & & pedogenic & 27.6 & 20.0 \\
\hline T-14 grab, Cut 1 & ASU & Trench 14 & & pedogenic & 26.1 & 20.0 \\
\hline T-14 grab, Cut 2* & ASU & Trench 14 & & pedogenic & 24.0 & 20.0 \\
\hline $7, \mathrm{P} 3$, Cut 1 & ASU & Trench 14 & & pedogenic & 22.8 & 20.0 \\
\hline $7, \mathrm{P3}, \mathrm{Cut} 2^{*}$ & ASU & Trench 14 & & pedogenic & 30.9 & 20.0 \\
\hline LANL 49, P1, Cut $2^{*}$ & ASU & Trench 14 & & pedogenic & 22.5 & 20.0 \\
\hline LANL 49, P1, Cut 1 & ASU & Trench 14 & & pedogenic & 31.3 & 20.0 \\
\hline HD-577b qtz & USGS & USW G-2 & 4116.4 & un-named lava & 5.9 & 15.8 \\
\hline HD-590b chal & USGS & USW G-2 & 5635.8 & un-named lava & 10.2 & 5.8 \\
\hline HD-406b tridy & USGS & USW GU-3 & 630 & & 11.5 & 20.1 \\
\hline $\mathrm{HD}-304 \mathrm{c} \mathrm{qtz}$ & USGS & UE-25 a\#1 & 780.6 & Topopah Spg & 11.3 & 17.2 \\
\hline HD-307b qtz & USGS & UE-25 a\#1 & 845.6 & Topopah Spg & 17.9 & 16.4 \\
\hline HD-308a tridy & USGS & UE-25 a\#1 & 898.1 & Topopah Spg & 12.5 & no cal \\
\hline HD-1497b qtz & USGS & UE-25 NRG\#2 & 187 & & 20.8 & 19.8 \\
\hline HD-1500a qtz & USGS & UE-25 NRG\#2 & 210.5 & & 8.6 & no cal \\
\hline HD-939-1-c qtz & USGS & Bullfrog Mine & 958 bench & & 5.6 & 5.8 \\
\hline HD-940c opal & USGS & Bullfrog Mine & 1024 bench & & 24.8 & 19.2 \\
\hline HD-941f qtz & USGS & Bullfrog Mine & 1042 bench & & 8.5 & 5.0 \\
\hline HD-94lg opal & USGS & Bullfrog Mine & 1042 bench & & 21.5 & 5.0 \\
\hline HD-1184c qtz & USGS & ESF & & & 19.4 & 19.5 \\
\hline HD-1189c qtz & USGS & ESF-6 & & & 16.8 & 19.4 \\
\hline HD-1189d qtz & USGS & ESF-6 & & & 14.1 & 19.4 \\
\hline HD-1191b qtz & USGS & ESF-8, bag 3 & & & 20.7 & 19.3 \\
\hline HD-119lc chal & USGS & ESF-8, bag 3 & & & 14.6 & 19.3 \\
\hline HD-270b qtz & USGS & USW G-3 & 4803 & & 6.9 & 7.5 \\
\hline HD-1 186f qtz & USGS & ESF-3 & & & 19.0 & 17.1 \\
\hline HD- $1186 \mathrm{~g}$ chal & USGS & ESF-3 & & & 7.9 & 17.1 \\
\hline HD-1186h qtz & USGS & ESF-3 & & & 20.2 & 17.1 \\
\hline
\end{tabular}

40 Applications of Isotope Geochemistry to the Reconstruction of Yucca Mountain, Nevada, Paleohydrology-Status of Investigations June 1996 